\title{
The influence of low amounts on in situ-polymerized bisphenol-diamine net in cement slurries prepared in seawater - structural analysis after long-term contact with in situ-generated mud-acid fracturing fluid
}

\author{
Influência de pequenas quantidades do bisfenol- \\ diamina polimerizado in situ em pastas de \\ cimento preparadas com água do mar-análise \\ estrutural após longo tempo de contato com fluído \\ de fraturamento mud acid gerado in situ
}

\author{
Danilo Oliveira Santos ${ }^{1}$, Ivory Marcos Gomes dos Santos ${ }^{1}$, \\ Joenesson Filip Santos Ribeiro ${ }^{2}$, Eunice Fragoso Silva Vieira ${ }^{2}$, \\ Gwenn Le Saoût ${ }^{3}$, Antonio Reinaldo Cestari ${ }^{1,2}$
}

\footnotetext{
${ }^{1}$ Department of Materials Science and Engineering, Federal University of Sergipe, CEP: 49100-000, São Cristóvão, Sergipe, Brazil.

e-mail: danilo.quimico@yahoo.com.br, ivorysantos@gmail.com, arcestari@gmail.com

${ }^{2}$ Laboratory of Materials and Calorimetry, Department of Chemistry/CCET, Federal University of Sergipe, CEP: 49100-

000, São Cristóvão, Sergipe, Brazil.

e-mail: joenesson.joe@ hotmail.com, eunice@ufs.br

${ }^{3}$ Lab. de Mécanique et Génie Civil (LMGC), IMT Mines Ales, Univ. Montpellier, CNRS, Ales, France.

e-mail: gwenn.le-saout@mines-ales.fr
}

\begin{abstract}
Inadequate zonal isolation in oil wells can provoke safety and environmental problems. New cement slurries can avoid such problems. In this work, novel cement slurries were prepared in the presence of seawater with in situ-formed epoxy resin-ethylenediamine. The new slurries were tested in relation to their mechanical properties and characterized by FTIR, XRD, TG/DTG, porosimetry by $\mathrm{N}_{2}$ adsorption-desorption and solidstate ${ }^{29} \mathrm{Si}$ and ${ }^{27} \mathrm{Al} \mathrm{NMR}$. Some kinetic features of long-term contact of the slurries with in situ-generated mud-acid were performed to evaluate the performances of the new slurries in routine acidizing procedures in oil well industry. The experimental kinetic data were well fitted to order-variable exponential kinetic model and a factorial design of four variables $\left(2^{4}\right)$. In these studies, it was possible to evaluate in detail how some important experimental factors act on the quantities of acid that interact with the pastes, as well as to verify how these factors affect the speed with which the mud-acid interacts with the slurries. The results strongly suggest that the interactions occurred at epoxy/ethylenediamine cement slurry/mud-acid interfaces are due to surface reactions with preservation of the chemical structures of the cement slurries, even after long-term contact with mud-acid. The new cement slurry present good features to be used in environmental-friendly procedures in oil well field.
\end{abstract}

Keywords: Epoxidized bisphenols; cement slurries; characterization of oil well materials; kinetic modeling; Multivariate analysis.

\section{RESUMO}

O isolamento zonal inadequado em poços de petróleo pode provocar problemas de segurança e ambientais. Novas pastas de cimento podem evitar esses problemas. Neste trabalho, novas pastas de cimento foram preparadas na presença de água do mar com resina epóxi-etilenodiamina formada in situ. As novas pastas foram testadas em relação às suas propriedades mecânicas e caracterizadas por FTIR, DRX, TG / DTG, porosimetria por adsorção-dessorção de $\mathrm{N}_{2}$ e RMN de ${ }^{29} \mathrm{Si}$ e de ${ }^{27} \mathrm{Al}$ no estado sólido. Algumas características cinéticas do longo tempo de contato das pastas com o mud acid gerado in situ foram realizadas para avaliar o desem- 
penho das novas pastas nos procedimentos rotineiros de acidificação na indústria de poços de petróleo. Os dados cinéticos experimentais foram bem ajustados ao modelo cinético exponencial de ordem variável e ao planejamento fatorial de quatro variáveis $\left(2^{4}\right)$. Nesses estudos, foi possível avaliar detalhadamente como alguns fatores experimentais importantes atuam sobre as quantidades de ácido que interagem com as pastas, bem como verificar como esses fatores afetam a velocidade com a qual o mud acid interage com as pastas. Os resultados sugerem fortemente que as interações ocorridas nas interfaces da pasta de cimento epoxi / etilenodiamina / mud acid são devidas a reações de superfície com preservação das estruturas químicas das pastas de cimento, mesmo após contato prolongado com mud acid. A nova pasta de cimento apresenta boas características para ser usada em procedimentos nos poços de petróleo.

Palavras-chave: Bisfenóis epoxidados; pastas de cimento; caracterização de materiais de poços de petróleo; modelagem cinética; Análise multivariada.

\section{INTRODUCTION}

Among other features, cement slurries have been used to block undesirable underground streams of oil, gas, water or the like $[1,2]$. Mainly for security reasons, oil well cementing has very low tolerance for failures. In this manner, new-engineered oil well cement slurries have been developed to enable adequate safe and longterm performance of oil and gas wells [2,3]. The so-called primary oil well cementing is made to provide a suitable and stable bond in underground formations, as well as to protect the pipe. Nowadays, cement-based materials have been developed to present chemical/physical stabilities and ensure adequate well durability.

The production levels of wells may be affected by the natural characteristics of the reservoir and damages from routine operations at great depths. In this way, acid fracturing has been a technique in oil industry for solving problems of some oil wells with impaired production. This technique consists in using acidic fluids to crack some rocks in specific underground environments, employing inorganic acid-based fluids, typically mud-acid, a mix of $\mathrm{HCl}$ and $\mathrm{HF}$ aqueous solutions [4]. However, such routine operations have been understood as an important aspect to oil and gas industries due to possible undesirable long-term reactions between the cement slurry in the annulus section and the acidic fluid, leading to the development of wormholes in some fractured interfaces. In many cases, undesirable chemical reactions result in soluble salts, which are leached away by underground water. From practical point of view, time-related rates of the acidic interactions are of utmost importance to choose a given cement slurry composition for long-term used in oil well field [5]. On the other hand, many molecular-level characteristics of hardened cement slurries remain unclear. It is mainly due to the partial destruction of the structure of cement-based materials after long-term contact with onshore/offshore oil well acidic environments [6-8]. In this way, suitable performances of oil well cement slurries have been reached by the use of some additives [6,7].

Some reactive polymeric additives have been observed to improve the structural features of hardened oil well cement bodies. In addition, the integration of polymer/cement is also known to provide lighten slurries, with better tensile strength, adhesions, and durabilities than cement slurries without such additives. Some polymers, such as styrene butadiene copolymers, PVC, and polyacrylics have been successfully applied in oil well procedures. Particularly, polymeric systems consisting of epoxy resins and diamines as hardeners have shown adequate aspects to be used in cement slurries formulations [9]. In such type of polymerized material, diglycidyl ether of bisphenol A, which is a product of reaction of bisphenol A and epichlorohydrin, is primarily cured by a given diamine producing a crosslinked polymerized resin, where thermal curing of the polymeric system is not a pre-requisite beforehand [10]. In fact, diamine-extended epoxy polymers have been reported to have excellent reactive characteristics in such polymeric system, where the presence of ether groups, polar aliphatic hydroxyls, and some residual unreacted amine groups provides strong interactions between bisphenol-type polymeric nets and cement [11,12]. Yet, another important advantage is that diamine-extended epoxy resins may be used in relatively low amounts in a given cement formulation (typically less than $10 \%$ in relation to cement mass), without loss of efficiency or remarkable changes of the rheological properties of the cement slurry [13]. On the other hand, the quality of the water used to mix oil well cement is a very important parameter and varies depending upon the technical specifications of cementing procedures.

Seawater has been used as the mix water for squeeze operations in offshore cementing procedures $[14,15]$. The advantages of the use of seawater in oil well cementing are related mainly to (1) ready availability, (2) relative low cost, since transportation can be eliminated, and (3) reduced fresh-water use and storage on offshore platforms. However, it is known that some components of seawater, such as $\mathrm{Cl}^{-}$and $\mathrm{SO}_{4}{ }^{2-}$, can cause changes in the compositions and properties of cement slurries. In addition, little is known on the characteristics of cement slurries after interaction with mud-acid. 
In this work, we report the preparation of cement slurries additived with epoxy resin and a diamine in the presence of seawater. The structural features of such material are also evaluated before and after longterm interaction with in situ-generated mud-acid in relation to contact time, initial concentration of the acid fluid and temperature. To the best of our knowledge, this is one of the very limited examples of long-term study of polymer-modified cement slurries in the presence of a little studied acidizing medium of mud-acid.

\section{MATERIALS AND METHODS}

\subsection{Materials}

Class A oil well cement and silica were both a free gift from Schlumberger - Petroleum Services Ltd (Nossa Senhora do Socorro, Sergipe State, Brazil), both presenting particles diameters of 300-325 mesh. The A/F bisphenol solution was from The Huntsman Co Special Resins, São Paulo, Brazil), which presents branched epoxidized oxirane rings in its chemical structure. Fig. 1 shows the chemical structures of the bisphenol resin and the hardener. Ethylenediamine, concentrated $\mathrm{HCl}$ aqueous solution (both from VETEC/Brazil) and tetrafluoroboric acid (Sigma-Aldrich) were all of analytical degree and used without purification. For comparative porpoises, different slurries preparations were made with double-distilled water and a seawater sample, which was collected near an off-shore oil well station in Aracaju, Sergipe State, Brazil.
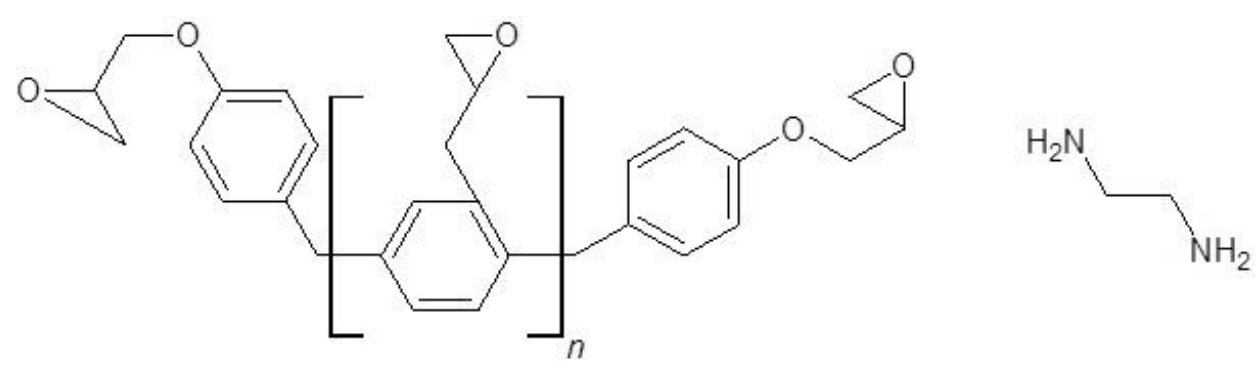

Figure 1: Chemical structures of the epoxy resin (left, $n=4-6)$ and the hardener (right).

\subsection{Methods}

\subsubsection{Preparation of the cement slurries}

The cements slurries were prepared as described earlier in literature [16,17], targeting hardened slurries with water/cement and silica/cement ratios of about 0.50 and 0.35 , respectively, and densities of about $1.75 \pm 0.12$ $\mathrm{g} / \mathrm{cm}^{3}$ [17,18]. Briefly, the main slurry was prepared with $200 \mathrm{~g}$ of cement, $70 \mathrm{~g}$ of powder silica, $100 \mathrm{~mL}$ of seawater, and a mixture of 5:5 (\%, in relation to cement mass) of A/F bisphenol solution and ethylenediamine. The cement suspension obtained was mixed at 4,000 rpm for $15 \mathrm{~s}$ (pre-mixing of the wet and dried components) and 35s at 12,000 rpm for an enough mixing of all components of the wet slurry. The demolded specimens were cast into $5.0 \mathrm{~cm}$ side cubic molds and stored in a desiccator saturated with water vapor at room temperature for $3 \mathrm{~h}$ prior to removal from the molds. The cement specimens were then cured directly in seawater for 28 days at $25^{\circ} \mathrm{C}$. Slurry with only cement, silica and seawater, as a control material, was prepared and hydrated using the same procedure. Additionally, the same slurries were also prepared and cured using bidestilled water instead of seawater. For simplicity, the cement slurries are hereafter denominated as slurrystandard-SW (cement/silica/seawater), slurry-standard-W (cement/silica/bidestilled water), slurry-MOD-SW (cement/silica/polymeric modifier, seawater) and slurry-MOD-W (cement/silica/polymeric modifier, bidestilled water). Samples were carefully removed from the surface of the cemented specimens and characterized.

\subsubsection{Long-term immersion tests in in situ-produced mud-acid}

The immersion experiments were made by isothermal procedures from 25 to $55 \pm 0.1{ }^{\circ} \mathrm{C}$ for approximately 90 hours, using mud-acid aqueous solutions from 0.01 to $0.1 \mathrm{molL}^{-1}$ in relation to their total acidic content of the solutions. The mud-acid was a mixture of $12 \% \mathrm{HCl}+3 \% \mathrm{HF}$, where the $\mathrm{HF}$ was in situ-generated from a reaction of tetrafluoroboric acid in water [19]. In a typical experiment at a given temperature, $50 \mathrm{~mL}$ of mudacid were added to $100 \mathrm{mg}$ of determined slurry in a $150 \mathrm{~mL}$ polyethylene flask and continuously stirred. Samples were taken at predetermined times and the total acidic content of the solution was determined by a 
$\mathrm{pH}$-meter or acid-base titrations using $0.01 \mathrm{~mol} \mathrm{~L}^{-1} \mathrm{NaOH}$ solutions. All experiments were carried out in triplicate runs. The amounts of total acidic species interacted with the slurries in relation to contact time $\left(\mathrm{Q}_{t}\right)$ were calculated using the expression [20]:

$$
Q_{t}=\frac{\left(C_{i}-C_{f}\right) \cdot V}{m}
$$

where $Q_{t}$ is the interacted amount of acidic species per gram of slurry in mol $\mathrm{g}^{-1}, \mathrm{C}_{\mathrm{i}}$ is the initial concentration of acidic species in solution, in $\mathrm{mol} \mathrm{L}^{-1}, \mathrm{C}_{\mathrm{f}}$ is the concentration of acidic species after a given contact time, in $\mathrm{mol} \mathrm{L}^{-1}, \mathrm{~V}$ is the volume of the solution in $\mathrm{L}$, and $\mathrm{m}$ is the mass of slurry in $\mathrm{g}$.

A factorial design study was also conducted to determine principal and interaction effects of selected experimental factors of mud-acid interaction onto the slurries. Such types of effects were calculated using Eq. 2:

$$
\text { Effect }=\bar{R}_{+, i}-\bar{R}_{-, i}
$$

where and are average values of $\mathrm{Q}_{t}$ for the high $(+)$ and low (-) levels of each factor. For principal effects, the above averages simply refer to the results at high $(+)$ and low $(-)$ levels of a given factor, which was calculated regarding the levels of the other factors. For binary interactions, is the average of results for the factors at their high and low levels, whereas is the average of the results for which one of the factors involved is at the high level (+) and the other is at the low level (-). High-order interactions are calculated using Eq (2), applying signs obtained by multiplying those for the factors involved for high and for low levels. Since duplicate runs were performed for each individual factorial design experiment, standard errors (E) of the effects were calculated by Eq. (3):

$$
E=\left\{\sum\left(d_{i}\right)^{2} / 8 N\right\}^{1 / 2}
$$
formed.

where $d_{i}$ represents the difference of each duplicate value and $\mathrm{N}$ is the number of the experiments per-

\subsubsection{Characterization of the samples}

Infrared spectral spectra were obtained on a Varian FTIR spectrophotometer, model 640 using $\mathrm{KBr}$ presseddisks technique at room temperature was used in the spectral range from 4000 to $900 \mathrm{~cm}^{-1}$. Thermal analysis curves (TG/DTG) were obtained with about $10 \mathrm{mg}$ of a given slurry under nitrogen atmosphere at $10^{\circ} \mathrm{C} \mathrm{min}$ ${ }^{1}$ from 25 to $900^{\circ} \mathrm{C}$, in a SDT 2960 thermoanalyzer from TA Instruments. The X-ray diffraction (XRD) diffractograms of the samples were obtained in a Shimadzu LABX 6000 diffractometer (CuK $\alpha$ radiation; $\lambda=$ $1.5400 \AA, 2 \theta=5-60^{\circ}$ ), with accumulation rate of $0.02^{\circ} \mathrm{min}^{-1}$. The porosity characteristics of the cement slurries were determined by $\mathrm{N}_{2}$ adsorption-desorption experiments performed at $77 \mathrm{~K}$ on a NOVA 1200 analyzer. The specific surface area (SBET) was determined from the Brunauer-Emmet-Teller (BET) equation. Pore size distributions were estimated using the Barrett-Joyner-Halenda method.

The ${ }^{29} \mathrm{Si}$ and ${ }^{27} \mathrm{Al}$ MAS NMR spectra were obtained using a Bruker Avance 400 NMR spectrometer using $\mathrm{ZrO}_{2}$ rotors, as described earlier [17]. The ${ }^{29} \mathrm{Si}$ chemical shifts were referenced to tetramethylsilane (TMS) at $0.0 \mathrm{ppm}$ and the ${ }^{29} \mathrm{Si}$ isotropic chemical shifts were resolved and measured to $\pm 0.1 \mathrm{ppm}$. The field strength was of $9.4 \mathrm{~T}$ at $79.49 \mathrm{MHz}$, with $5 \mathrm{kHz}$ spinning rates on a $7.5 \mathrm{~mm} \mathrm{CP} / \mathrm{MAS}$ probe, with singlepulse experiments being carried out by applying 900 pulses with $1 \mathrm{H}$ decoupling and recycle delays of $10 \mathrm{~s}$. The ${ }^{27} \mathrm{Al}$ MAS NMR spectra were recorded on a Bruker Avance III $600 \mathrm{NMR}$ spectrometer. The ${ }^{27} \mathrm{Al}$ chemical shifts were referenced relative to a $1.0 \mathrm{~mol} \mathrm{~L}^{-1} \mathrm{AlCl}_{3}-6 \mathrm{H}_{2} \mathrm{O}$ solution at $0.0 \mathrm{ppm}$. The field strength was $14.1 \mathrm{~T}$ at $156.33 \mathrm{MHz}$, with $20 \mathrm{kHz}$ spinning rates on a $3.2 \mathrm{~mm}$ CP/MAS probe using also $\mathrm{ZrO}_{2}$ rotors. Single-pulse experiments were carried out by applying $\pi / 12$ pulses and recycle delays of $1 \mathrm{~s}$.

Mechanical tests of the specimens were carried out on an Instron Universal Testing Machine, model $3385 \mathrm{H}$. The compressive strength test used a $250 \mathrm{kN}$ load cell with a loading speed of $0.5 \mathrm{~mm} \cdot \mathrm{min}^{-1}$. The moduli of elasticity of the samples were obtained from slope of the linear region of the load-displacement curve. 


\section{RESULTS}

\subsection{Characterization of the cement samples}

Characterization has been an important tool for understanding the relationship chemical compositionmolecular structure associated of hydrated cement slurries. Furthermore, characterization is intended in this work to provide additional molecular-level information after the cement slurries were in long-term contact with chemically aggressive acidic media. Cement slurries are indeed a multiphase and complex class of materials.

Typically, there are four main mineral phases in oil-well cements [1]: tricalcium silicate $\left(\mathrm{C}_{3} \mathrm{~S}\right.$, $\left.\mathrm{Ca}_{3} \mathrm{SiO}_{5}\right)$, dicalcium silicate $\left(\mathrm{C}_{2} \mathrm{~S}, \mathrm{Ca}_{2} \mathrm{SiO}_{4}\right)$, tricalcium aluminate $\left(\mathrm{C}_{3} \mathrm{~A}, \mathrm{Ca}_{3} \mathrm{Al}_{2} \mathrm{O}_{6}\right)$, and calcium aluminoferrite $\left(\mathrm{C}_{4} \mathrm{AF}\right)$ of different compositions. Upon hydration, the calcium silicate hydrate $(\mathrm{C}-\mathrm{S}-\mathrm{H})$ is formed, being a relatively poorly crystalline material consisting firstly of nonstoichiometric dimeric units, which present slow polymerization to give higher linear pentamers and octamers. A number of methods has been used to characterize amorphous and crystalline components of cements.

Figs. 2 and 3 show the FTIR spectra of the slurries, before and after mud-acid interaction. However, analysis of some bands in the mid-IR spectra $\left(2800-4000 \mathrm{~cm}^{-1}\right)$ is indeed difficult due to the presence of broad bands and bands overlaps. Anyway, this technique enables to find some features of physically adsorbed water, silicate polymerization, possible presence of $\mathrm{Ca}(\mathrm{OH})_{2}\left(\mathrm{CH}\right.$, portlandite) and $\mathrm{TO}_{4}$-type condensed tetrahedral in cement chains $(\mathrm{T}=\mathrm{Si}$ or $\mathrm{Al}$ in $\mathrm{Si}-\mathrm{O}-\mathrm{Si}$ or Al-O-Si bonds), as well as possible presence of calcium carbonate polymorphs [21].

For the standard slurries (Fig. 2, a) and c)), the small narrow bands at 3,640 and 3,642 $\mathrm{cm}^{-1}$ are due to $\mathrm{CH}$ (Ca-OH vibrations). The broad bands centered at 3446 and $1690 \mathrm{~cm}^{-1}$ are due to $\mathrm{O}-\mathrm{H}$ groups in $\mathrm{H}_{2} \mathrm{O}$ or hydroxyls groups of hydrated products, which present several hydrogen bond strengths [22]. The band centered at around $1081 \mathrm{~cm}^{-1}$ is assigned to $\mathrm{Si}-\mathrm{O}$ stretching vibrations of the $\mathrm{SiO}_{4}$ tetrahedral units, from residual unreacted silica or C-S-H mixes [23]. Condensation reactions between $\mathrm{Al}-\mathrm{OH}$ and $\mathrm{Si}-\mathrm{OH}$ groups, forming aluminosilicate bonds, can also occur. The Si-O stretching bands, however, usually overlap ettringite $\left(\mathrm{Ca}_{6} \mathrm{Al}_{2}\left(\mathrm{SO}_{4}\right)_{3}(\mathrm{OH})_{12} \cdot 26 \mathrm{H}_{2} \mathrm{O}\right)$ bands at around $1000 \mathrm{~cm}^{-1}$ and $1120 \mathrm{~cm}^{-1}$. The band at $453 \mathrm{~cm}^{-1}$ is associated with bending vibrations of $\mathrm{O}-\mathrm{Si}-\mathrm{O}$ groups, which is influenced by $\mathrm{O}-\mathrm{Si}-\mathrm{O}$ angles or influence of neighboring sites. Bands of calcium carbonate can be found at about 1420 and $850 \mathrm{~cm}^{-1}$. Typically, the presence of crystal structures of calcium carbonate polymorphs (vaterite, aragonite and calcite) can be made using FTIR. In this manner, the small bands centered at 873 and $1427 \mathrm{~cm}^{-1}$ suggest the presence of aragonite [24]. The mid-IR bands changed in frequency, which are related with silicate reactions after mud-acid interaction [25,26]. The bands at 3640 and $1086 \mathrm{~cm}^{-1}$ are not clearly observed after mud-acid interaction suggesting, respectively, partial reactions of leaching of $\mathrm{CH}$ and depolymerization with rearrange of silicates chains, leading to formation of new aluminosilicates [27].

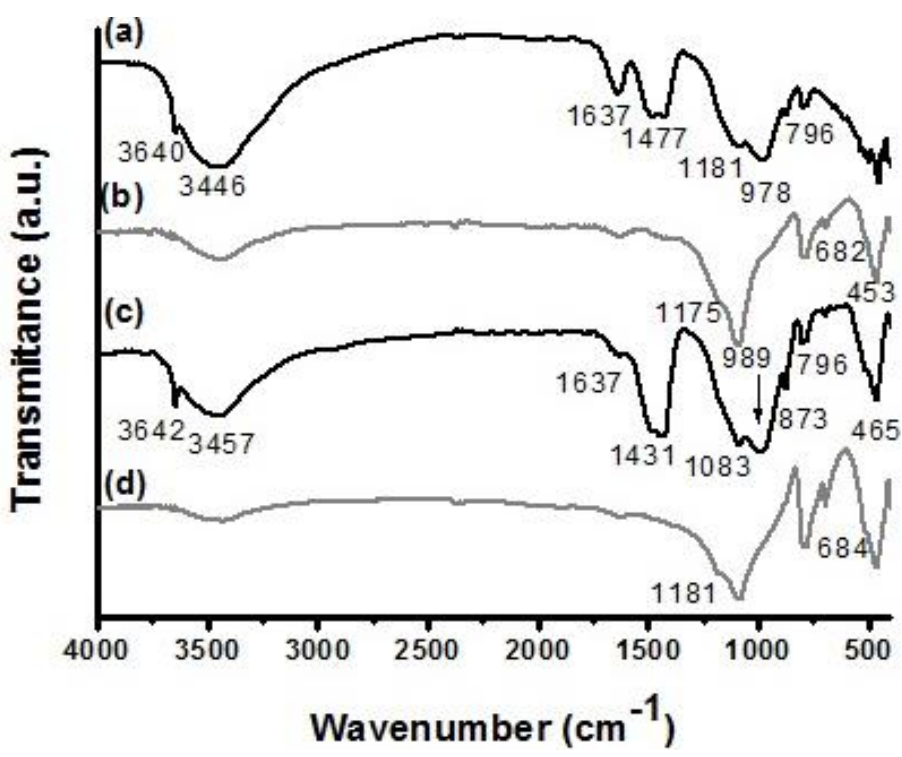

Figure 2: FTIR spectra of the standard slurries: a) Slurry-Standard-W; b) Slurry-Standard-W after mud-acid interaction; c) Slurry-Standard-SW and d) Slurry-Standard-SW after mud-acid interaction. 


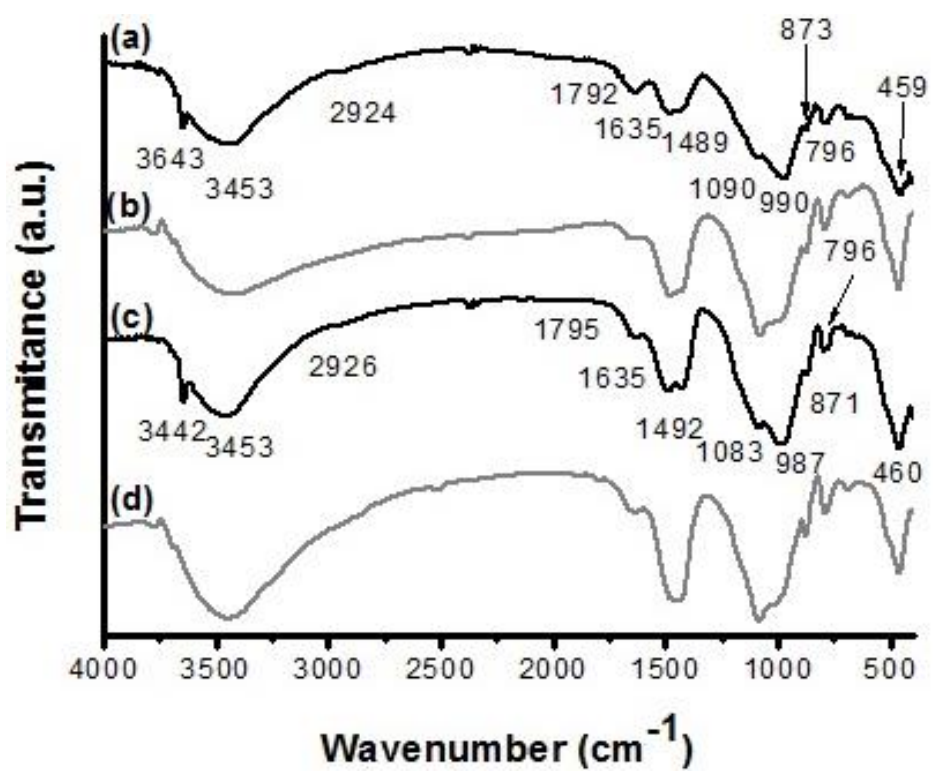

Figure 3: FTIR spectra of the modified slurries: a) Slurry-MOD-W; b) Slurry-MOD-W after mud-acid interaction; c) Slurry-MOD-SW and d) Slurry-MOD-SW after mud-acid interaction.

Regardless of the characterization technique used, the identification of polymers within cement-based matrixes has been a major problem, due to the low amounts of such compounds in cement samples. Looking at the FTIR spectra of the chemically modified cement materials (Fig.3) the formation of epoxy/ethylenediamine polymeric net seems to cause reorganizations of hydrated cement microstructure. The presence of very small broad bands at 2925 and $1795 \mathrm{~cm}^{-1}$ are due to both alkyl $\left(-\mathrm{CH}_{3},-\mathrm{CH}_{2}\right)$ and ester ($(\mathrm{C}=\mathrm{O})-\mathrm{O})$ groups of the epoxy resin, respectively. At $3643 \mathrm{~cm}^{-1}$ only a shoulder appears, which may correspond to interactions (probably hydrogen bondings) between hydrated cement phases and the epoxyethylenediamine polymeric net $[28,29]$. This may be occurred due to the inhibitive effect of the epoxyethylenediamine resin on the formation of $\mathrm{CH}$ during the hydration of the slurry-MOD. The FTIR spectrum of slurry-MOD after exposure to mud-acid is more or less unchanged in relation to the pristine slurry-MOD. It seems to be a first evidence of the effect of the Epoxy-Ethylenediamine resin (Epoxy-EDA) against the leaching out some chemical components of the polymer-modified cement slurry in the presence of mud-acid.

The XRD plots of the slurries are presented in Figs. 4 and 5. XRD powder diffractions of hydrated cement materials are related to identification of phase composition, possible determination of polymorphic modifications and analysis of crystallinity of individual phases. Some products, however, do not present clear diffraction peaks. In addition, some XRD peaks from different components may coincide or overlap. 


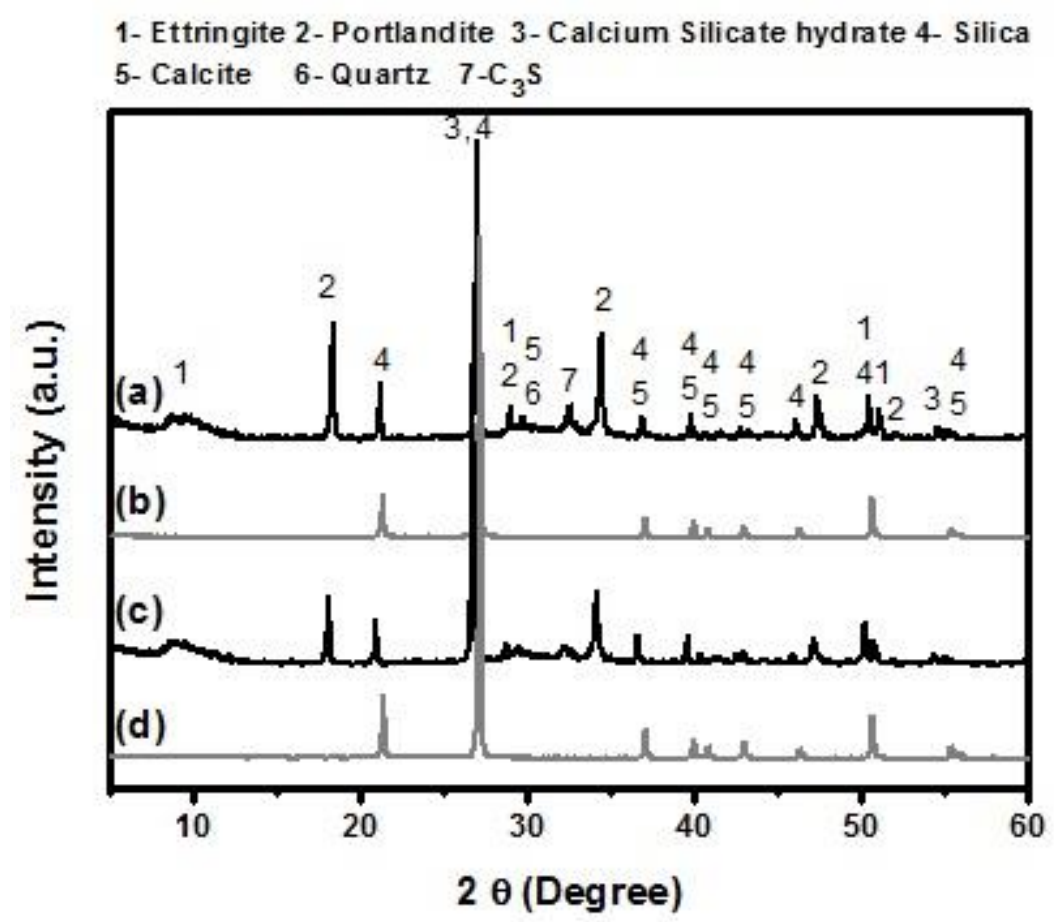

Figure 4: XRD diffractograms of the standard slurries: a) Slurry-Standard-W; b) Slurry-Standard-W after mud-acid interaction; c) Slurry-Standard-SW and d) Slurry-Standard-SW after mud-acid interaction.

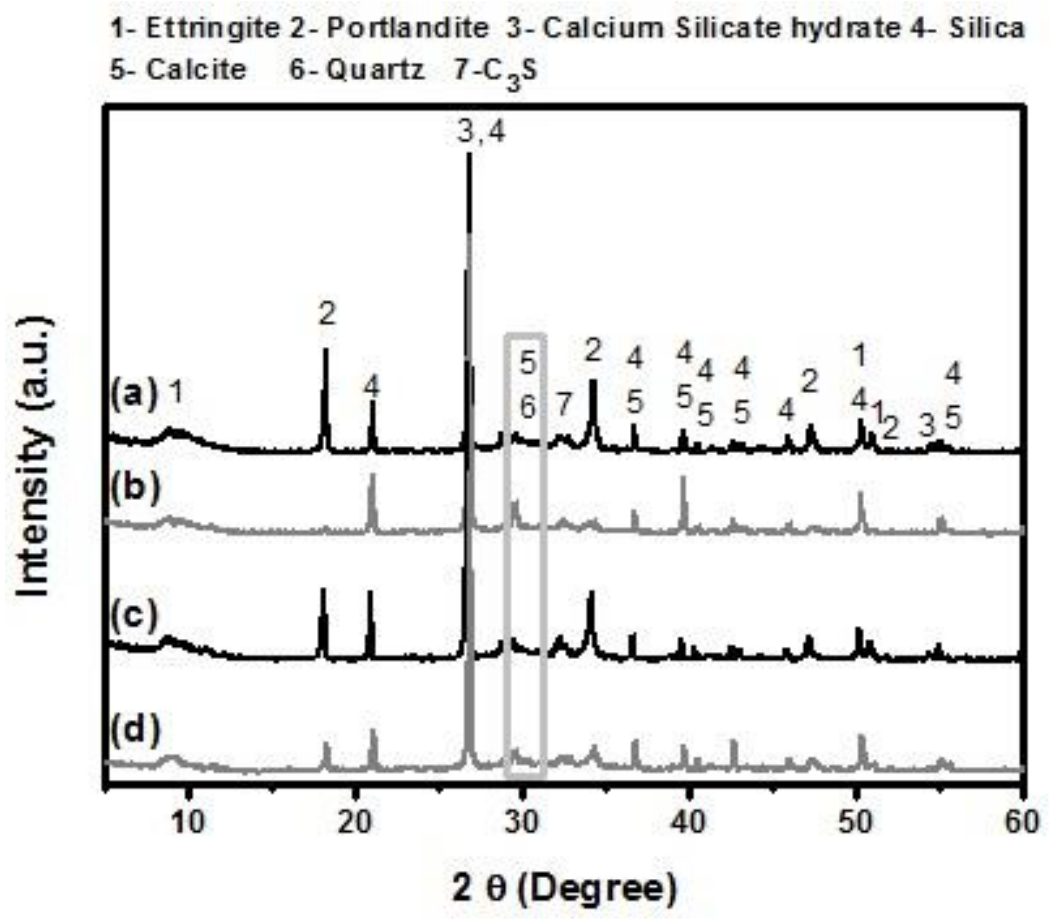

Figure 5: XRD diffractograms of the modified slurries: a) Slurry-MOD-W; b) Slurry-MOD-W after mud-acid interaction; c) Slurry-MOD-SW and d) Slurry-MOD-SW after mud-acid interaction.

The diffractograms of the standard slurries prepared in seawater and distilled water (slurry-standardSW and slurry-standard-W) show similar behavior one another, in which the presence of the most common hydrated compounds in the cement slurries is verified. For these slurries, the principal peaks are (in $2 \theta$, degree): $9^{\circ}$, ettringite; $18^{\circ}, \mathrm{CH} 21^{\circ}$, silica; $26^{\circ}, \mathrm{C}-\mathrm{S}-\mathrm{H}$ and $29^{\circ}$, calcite [30].

The main products of cement hydration are ettringite, $\mathrm{CH}$ and $\mathrm{C}-\mathrm{S}-\mathrm{H}$. The hydration of the calcium silicates produces a family of structurally similar, essentially amorphous or little crystalline silicates. $\mathrm{CH}$ is 
the second most abundant hydration product, forming crystalline aggregates [31,32]. Ettringite is formed by hydration of alita $\left(\mathrm{C}_{3} \mathrm{~S}\right)$ in the presence of gypsum (hydrated calcium sulfate). The formation of calcite (Ca$\mathrm{CO}_{3}$ ) is attributed to the partial carbonation of $\mathrm{CH}$ and presence of carbon dioxide dissolved in water [33]. The peak at $28^{\circ}$ refers to a mixture of quartz and calcite in the cement slurries [34]. The presence of $\mathrm{C}_{3} \mathrm{~S}$ $\left(32^{\circ}\right)$ in the diffractograms suggests that hydration was not complete.

Some aspects of microstructure of the standard slurries have changed after interaction with mud-acid. From analysis of the standard slurries XRD diffractograms, the crystalline aspect of these cement slurries decreased markedly (Fig. 4), where there are no peaks of the mains hydrated phases ( $\mathrm{CH}, \mathrm{C}-\mathrm{S}-\mathrm{H}$ and ettringite). Some features of chemical reactions of hydrated cement in the presence of acidic solutions have already been studied in detail. Under acid $\mathrm{pH}$, the constituents ( $\mathrm{CH}, \mathrm{C}-\mathrm{S}-\mathrm{H}$, calcium aluminate hydrates) dissolve at various velocities over contact time and new salts precipitate. The first and faster dissolving component is $\mathrm{CH}$ along the neutralization reactions. In these chemical reactions, there is the formation of water-soluble calcium salts. The strength of the attack is considered mainly dependent on the solubility of the precipitated salts. After leaching the $\mathrm{CH}$ to the solution, the matrix C-S-H is attacked. Under appropriate conditions, the chemical attack may result in the complete decomposition of the hydration products [35]. Thus, the degradation of the constituents of these slurries with possible restriction to the added silica is evidenced.

Figure 5 shows the diffractograms of modified slurries before and after and the interaction with the mud-acid. The diffractograms of the slurry-MOD-SW and slurry-MOD-W did not exhibit additional peaks when compared to the standard slurries. The results of X-ray diffraction analysis show that there is no significant difference between the hydration products of standard slurry and modified slurry with Epoxy-EDA as predicted in the literature [36]. Slurry-MOD presented the following main peaks: $9^{\circ}$ ettringite, $18^{\circ} \mathrm{CH}, 21^{\circ}$ silica, $26^{\circ} \mathrm{C}-\mathrm{S}-\mathrm{H}$ and $29^{\circ}$ Calcite. The diffractograms of the slurries, after interaction with mud-acid are similar to those materials before interaction with mud-acid. For these materials, there is a decrease of intensity in the peaks of $\mathrm{CH}$, confirming data from the literature that this phase undergoes preferential decomposition [37]. The peak at $28^{\circ}$ for the quartz-calcite mixture is highlighted in the diffractograms of these modified cement slurries, and still found after mud-acid attack. Therefore, it is verified that the presence of EpoxyEDA polymer protected quartz from chemical degradation. The microstructures of the polymer-modified slurries remain relatively unchanged, even after the interaction with mud-acid.

The results from the TG/DTG tests are shown in Figs. 6 and 7. Thermal analysis can be used to quantitatively determine mass loss of liquids (typically $\mathrm{H}_{2} \mathrm{O}$ ), gases, as well as to indicate the presence of some cement phases, which do not evidenced using XRD technique, because this technique only shows slurries crystalline phases. However, the identification of mineral components and their quantification is a difficult task due to temperature-related overlapping processes [38].

The TG/DTG plots profiles help to evaluate the typical reactions occurring in the cement-based slurry when subjected to a progressive temperature increase. Figure 6 shows the TG/DTG plots of standard slurries. Standard slurries (Slurry-Standard-SW and Slurry-Standard-W) have shown similar TG/DTG curves one another. Typically, there are three main mass losses regarding to the release of evaporation of physically adsorbed water on the surfaces and pores of slurries, as well as to the decomposition of hydrated calcium silicate and ettringite $\left(60-200^{\circ} \mathrm{C}\right)$, the decomposition of $\mathrm{CH}\left(410-500^{\circ} \mathrm{C}\right)$ and the calcination of amorphous materials and calcite $\left(\mathrm{CaCO}_{3}\right)$, according to equation (4) [24]:

$$
\mathrm{CaCO}_{3(\mathrm{~s})} \rightarrow \mathrm{CaO}{ }_{(\mathrm{s})}+\mathrm{CO}_{2(\mathrm{~g})}
$$



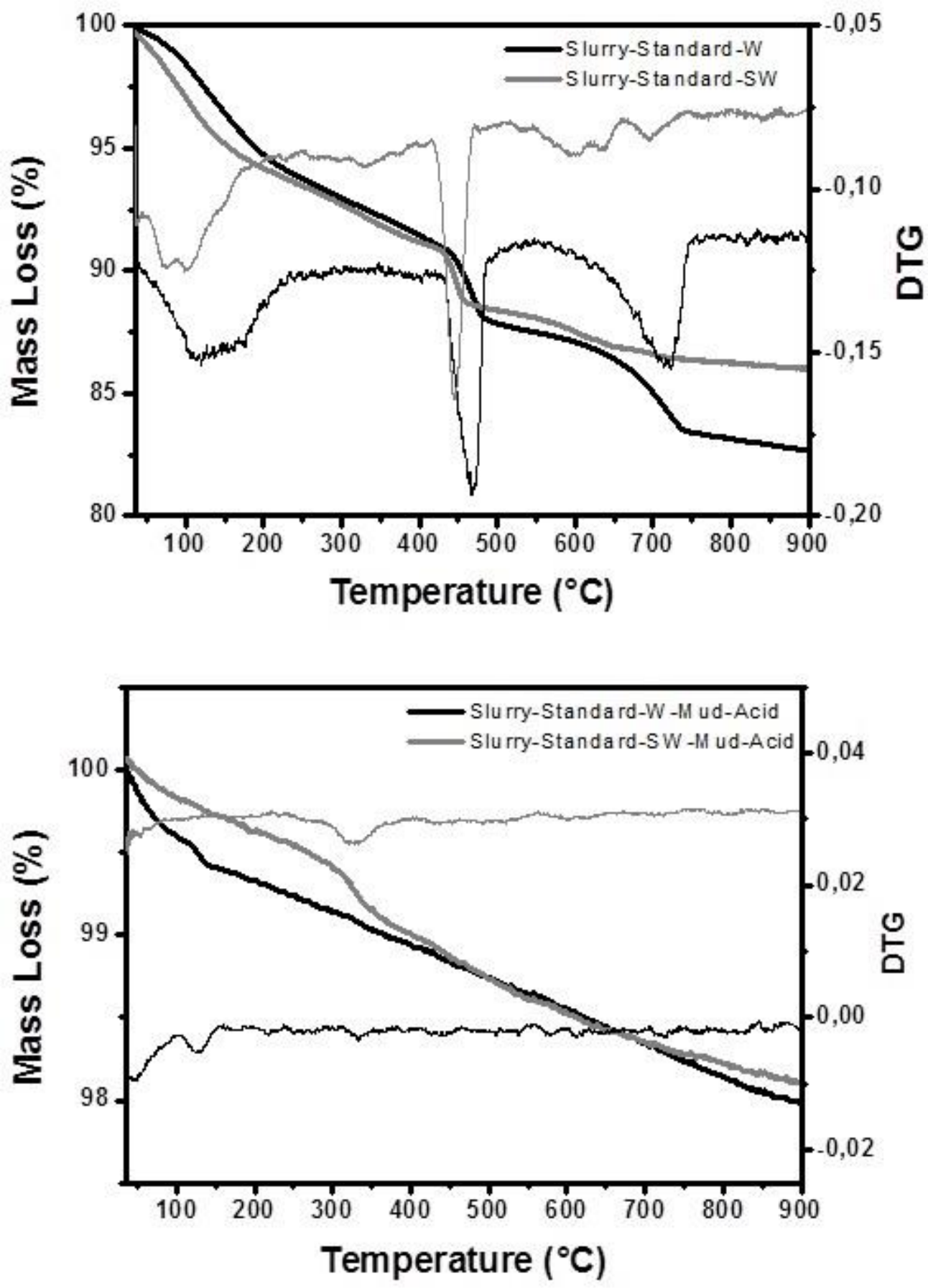

Figure 6: TG and DTG plots of the standard slurries before (above) and after (below) mud-acid interaction.

Figure 7 shows the TD/DTG curves of modified slurries with the Epoxy-EDA polymer (Slurry-MODSW e Slurry-MOD-W). The TG/DTG curves of these materials present five main mass losses, with some mass loss overlays. The mass loss located below $100^{\circ} \mathrm{C}$ is attributed to the removal of physically adsorbed water in the cement slurry and the event in $160^{\circ} \mathrm{C}$ refer to the decomposition of $\mathrm{C}-\mathrm{S}-\mathrm{H}$ and ettringite. The event between $280-400^{\circ} \mathrm{C}$ refers to the decomposition of the Epoxy-EDA polymer. The mass loss located between 410 and $500^{\circ} \mathrm{C}$ is attributed to the $\mathrm{CH}$ decomposition and two overlapping events between 710 $800^{\circ} \mathrm{C}$ are characteristic of the calcination of amorphous materials and calcite $[39,40]$. 

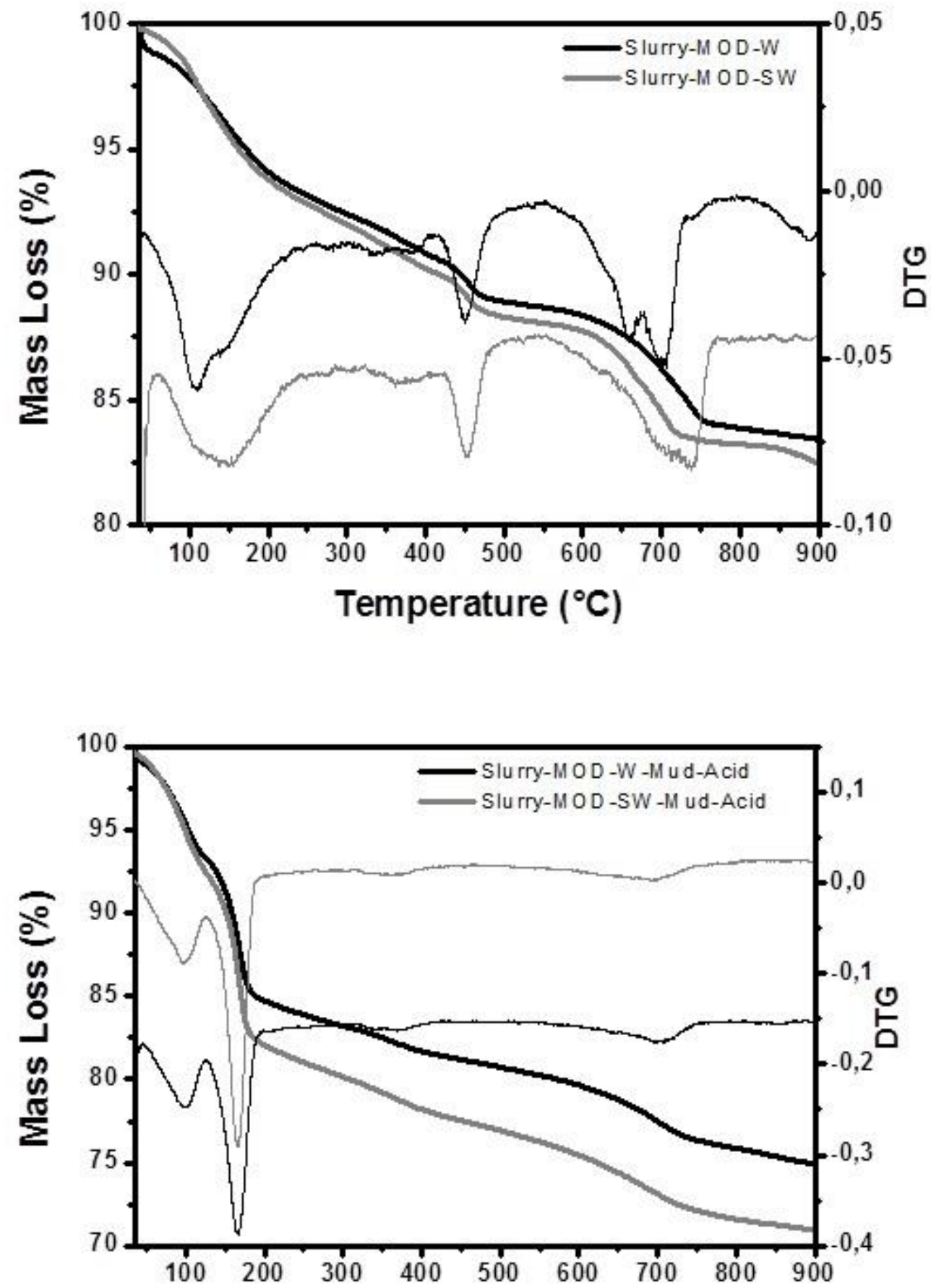

Figure 7: TG and DTG plots of the modified slurries before (above) and after (below) mud-acid interaction.

The TG/DTG plots of the standard slurries after mud-acid interactions present distinct profiles of data before contact. The percentage of mass loss of these slurries was approximately $2 \%$. In the TG/DTG curve of the Slurry-Standard-SW after acid contact show mass loss around $330^{\circ} \mathrm{C}$ attributed to the presence of $\mathrm{Fe}_{2} \mathrm{O}_{3}$ produced from tetracalcium ferro-aluminate during the cement hydration reaction [41]. However, the TG/DTG curves of Slurry-MOD after exposure to mud-acid solution is more or less the same in relation to the modified slurry before mud-acid interaction.

The $\mathrm{CH}$ content were estimated from the weight loss measured from each TG plots between the initial and final temperature of a given mass loss process corresponding TG peak by considering the following decomposition reaction $\left(410-500^{\circ} \mathrm{C}\right)$, according to Eq. 5 [32]:

$$
\mathrm{Ca}(\mathrm{OH})_{2(\mathrm{~s})} \rightarrow \mathrm{CaO}_{(\mathrm{s})}+\mathrm{H}_{2} \mathrm{O}_{(\mathrm{g})}
$$


From TG/DTG curves, the portlandite content was determined using Eq. (6) [32]. Table 1 shows the values of the percentage of $\mathrm{CH}$ in each cement slurry.

$$
C H(\%)=\frac{\Delta \mathrm{CH}(\%) \cdot \mathrm{MM}_{\mathrm{CH}}}{\mathrm{MM}_{\mathrm{W}}}
$$

where $\mathrm{CH}(\%)$ is content portlandite, $\Delta \mathrm{CH}(\%)$ is the weight loss during the decomposition of $\mathrm{CH}$, $\mathrm{MM}_{\mathrm{CH}}$ is the molar weight of $\mathrm{CH}$ and $\mathrm{M}_{\mathrm{W}}$ is the molar mass of water.

Table 1: Quantity of portlandite present in cement slurries.

\begin{tabular}{c|c}
\hline MATERIAL & CH (\%) \\
\hline $\begin{array}{c}\text { Slurry-Standard-SW-Standard-SW-Mud- } \\
\text { Acid }\end{array}$ & 11.41 \\
\hline $\begin{array}{c}\text { Slurry-Standard-W } \\
\text { Acid }\end{array}$ & Not found \\
\hline $\begin{array}{c}\text { Slurry-Standard-W-Mud- } \\
\text { Slurry-MOD-SW }\end{array}$ & Not found \\
\hline Slurry-MOD-SW-Mud-Acid & 6.97 \\
\hline Slurry-MOD-W & 5.15 \\
\hline Slurry-MOD-W-Mud-Acid & 6.97 \\
\hline
\end{tabular}

Standard slurries have higher amounts of $\mathrm{CH}$ than the modified slurries with Epoxy-EDA polymer. A possible explanation may be the interaction of the polymers at the at the $\mathrm{CH}$ nucleation sites, which prevents the growth of their crystals [32]. The presence of polymers can significantly influence the morphology of $\mathrm{CH}$ in cement matrices, depending on the type of polymer, the proportion of polymer in the cement or a combination of all these factors [42]. After the mud-acid attack, the amount of $\mathrm{CH}$ was calculated only for the modified slurries, since for the standard slurry no thermal events of mass losses attributed to the presence of $\mathrm{CH}$ were identified. For modified slurries, the percentage of $\mathrm{CH}$ was lower after the acid attack suggesting partial destruction of the $\mathrm{CH}$ structures in the slurries containing the Epoxy-EDA polymer.

It has been shown that the presence of Epoxy-EDA can significantly influence the properties of cement slurries. It was evidenced that modified slurries presented superior behavior in relation to the standard slurries against to acid attack, suggesting that the polymer directly influenced the resistance of the slurries. These all conclusions from TG/DTG curves seem to be very consistent with results from FTIR and XRD characterization.

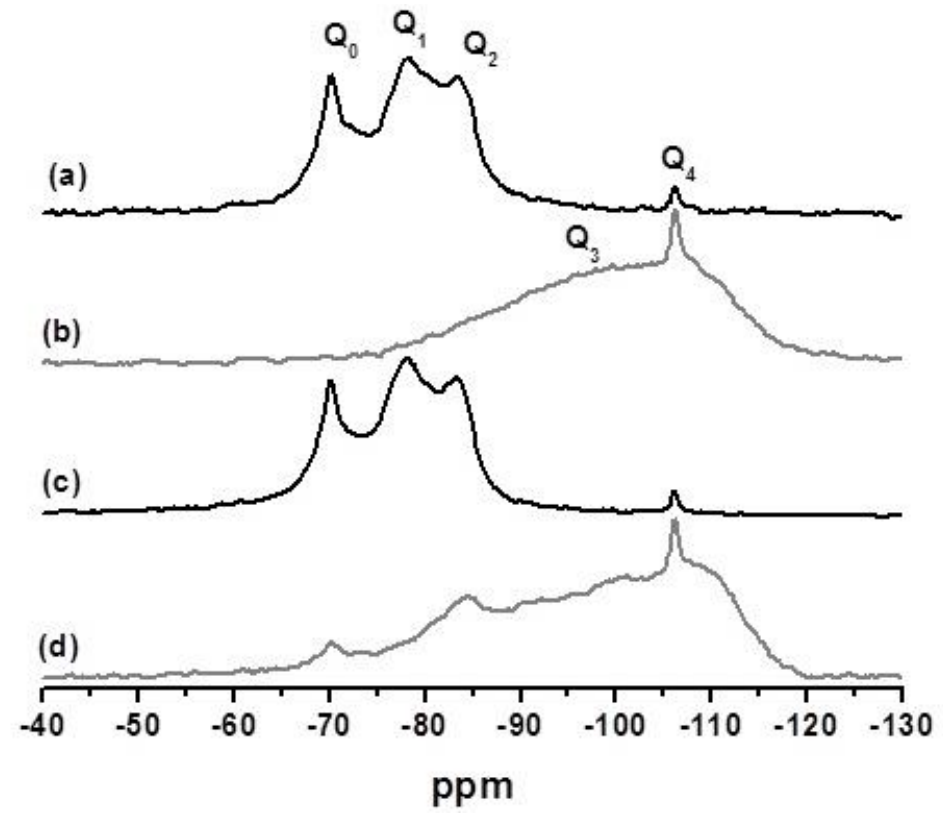

Figure 8: ${ }^{29}$ Si MAS NMR spectra of the modified slurries: a) Slurry-MOD-W; b) Slurry-MOD-W after mud-acid interaction; c) Slurry-MOD-SW and d) Slurry-MOD-SW after mud-acid interaction. 
In general, ${ }^{29} \mathrm{Si}$ chemical shifts in silicates are located from -60 to $-120 \mathrm{ppm}$. In this work, the ${ }^{29} \mathrm{Si}$ chemical shifts were analyzed using the $\mathrm{Q} n(m \mathrm{Al})$ classification, where one given Si tetrahedron is connected to $n \mathrm{Si}$ tetrahedra $(n=0-4) ; m$ is the number of neighboring $\mathrm{AlO}_{4}$ tetrahedra [43]. The ${ }^{29} \mathrm{Si} \mathrm{NMR}$ spectra of modified slurries, before and after contact with mud-acid are shown in Figure 8 . The ${ }^{29} \mathrm{Si}$ NMR spectra of Slurry-MOD-SW and Slurry-MOD-W are similar. The spectra show near $-70 \mathrm{ppm}$ resonances from the $\mathrm{Q}_{0}$ units of the anhydrous cement (unreacted cement). The broad peaks with maxima at -78 and $84 \mathrm{ppm}$ are due to $\mathrm{Q}_{1}$ and $\mathrm{Q}_{2}$ units refer to polymeric end-chain tetrahedral and middle nonbridging tetrahedral units in polymer chain of C-S-H, respectively. The small broad peak of $\mathrm{Q}_{4}$ type site centered at $-106 \mathrm{ppm}$ is related to crystalline quartz $[43,44]$.

After contact with mud-acid, a small and broad $\mathrm{Q}_{3}$ peak is observed near $-98 \mathrm{ppm}$, which is referred to formation of highly polymerized amorphous alumino silicate phases [45]. The effect of mud-acid is more destructive for the C-S-H, mainly silica gel is present in both samples. C-S-H seems to be more resistant in the Slurry-MOD-SW. Interestingly, the $\mathrm{Q}_{4}$ peak remains in the ${ }^{29} \mathrm{Si} \mathrm{NMR}$ spectra, corroborating with the analyzes of XRD that indicate the presence of quartz after the contact with mud-acid solution [43].

${ }^{27} \mathrm{Al}$ NMR is used to differentiate $\mathrm{Al}$ in different coordination states in the structural characterization of aluminate phases in cement slurries [46] ${ }^{27} \mathrm{Al} \mathrm{NMR}$ data recorded are shown in Fig. 9. The ${ }^{27} \mathrm{Al} \mathrm{NMR}$ spectra of the modified slurries are quite similar. These spectra shown $\mathrm{Al}$ in fourfold coordination due to $\mathrm{Al}$ substituting $\mathrm{Si}$ in the $\mathrm{C}-\mathrm{S}-\mathrm{H}$. In the aluminum sixfold range, three main peaks are observed: ettringite at 13 ppm, Calcium Aluminate Monosulfate (AFm), around 9 ppm, and a small shoulder at around $3.5 \mathrm{ppm}$, which has been related to an amorphous aluminate phase, from precipitation reactions at the surface of a C-S-H or found as a separate phase (TAH) [46,47]. After interaction with mud-acid, Slurry-MOD-W show resonances from tetrahedrally coordinated $\mathrm{Al}(40-70 \mathrm{ppm})$, present amorphous alumino silicate phases and in range -10 to $20 \mathrm{ppm}$ can be attributed to octahedrally coordinated $\mathrm{Al}$ and third aluminate hydrate [47]. ${ }^{27} \mathrm{Al} \mathrm{NMR}$ spectra of the Slurry-MOD-SW after contact with mud-acid is similar to Slurry-MOD-W with additional chemical shift value attributed to AFm at $9 \mathrm{ppm}$.

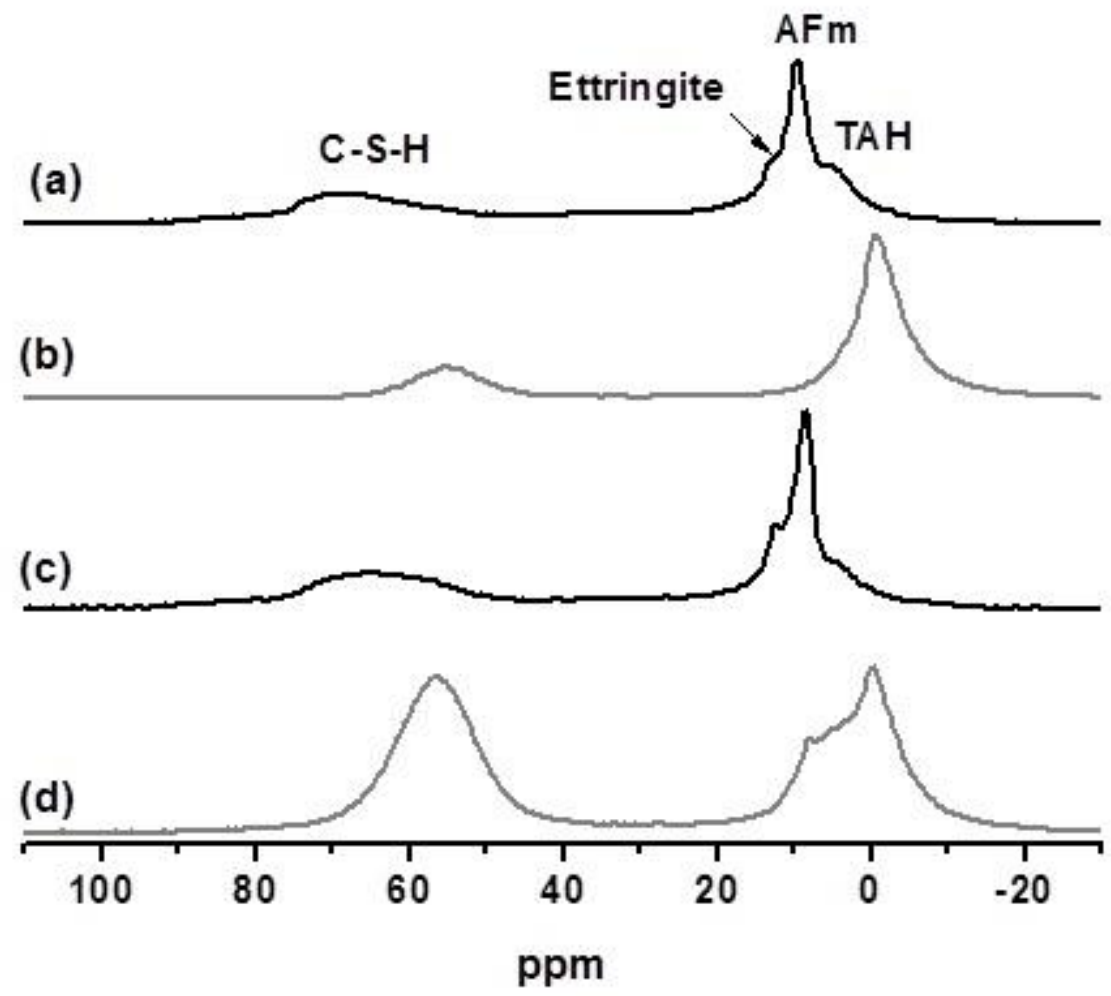

Figure 9: ${ }^{27} \mathrm{Al}$ MAS NMR spectra of the modified slurries: a) Slurry-MOD-W; b) Slurry-MOD-W after mud-acid interaction; c) Slurry-MOD-SW and d) Slurry-MOD-SW after mud-acid interaction. 
For standard slurries, the process of acidic attack resulted in the total decomposition of the hydration products and silica as shown in the previous characterizations (details not shown). Similar results were also observed earlier [17].
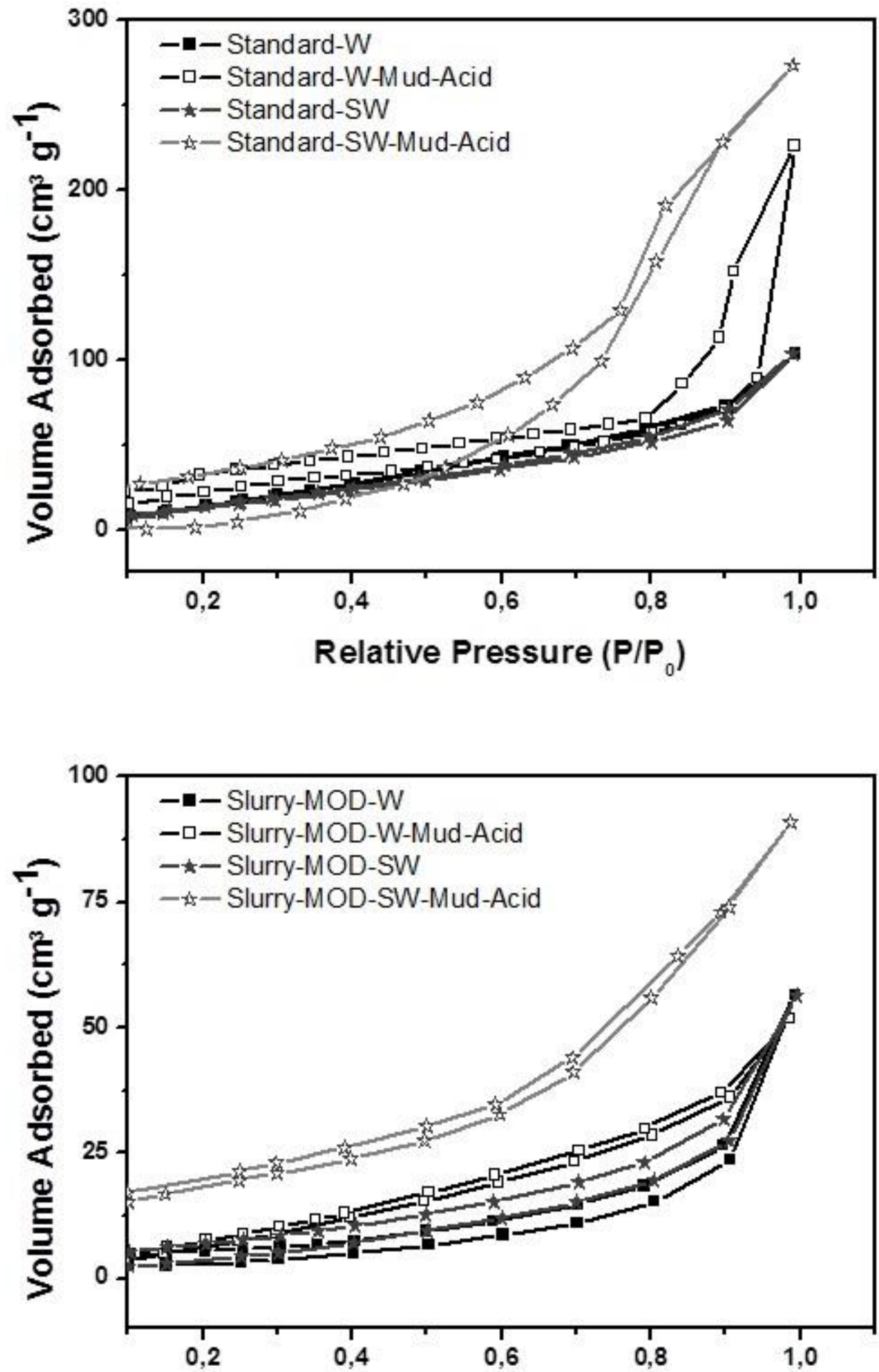

Figure 10: Adsorption-desorption isotherms of nitrogen at $77 \mathrm{~K}$ of standard slurries (above) and modified slurries (below). 
The features related to the porosity of the cement slurries are considered important to evaluate the durability of cement slurries. The porous structure has a direct effect on the chemical and mechanical resistance of cement slurries [48].

The porosity analysis of the cement slurries was performed, before and after an interaction with the mud-acid. The adsorption/desorption isotherms of the slurries before and after interaction with mud-acid solution are shown in Fig. 10. The cement slurries exhibited a Type II adsorption isotherms, according to IUPAC classification [48].

The isotherms of the standard slurries, after the acid attack, presented different profile in relation to the initial isotherm. After the interaction of these slurries with mud-acid solution, the isotherms showed hysteresis, suggesting that the nitrogen adsorption and its desorption process occurred in different ways, due to changes in the geometry and pore size of the slurries, as shown in Table 2. For modified slurries, the type II isotherm profile was maintained after contact with mud-acid solution, and the geometry and pore size remaining unchanged in these materials.

Table 2: Textural proprieties of the cement slurries.

\begin{tabular}{c|c|c|c}
\hline MATERIAL & SURFACE AREA $\left(\mathbf{m}^{2} \cdot \mathbf{g}^{-1}\right)$ & PORE VOLUME $\left(\mathbf{c m}^{\mathbf{3}} \cdot \mathbf{g}^{-1}\right)$ & PORE SIZE $(\tilde{\mathbf{A}})$ \\
\hline Slurry-Standard-W & 91.5 & 0.081 & 18.0 \\
\hline Slurry-Standard-W-Mud-acid & 147.7 & 0.156 & 22.6 \\
\hline Slurry-MOD-W & 11.8 & 0.024 & 18.2 \\
\hline Slurry-MOD-W-Mud-acid & 35.8 & 0.076 & 18.1 \\
\hline Slurry-Standard-SW & 74.6 & 0.072 & 18.0 \\
\hline Slurry-Standard-SW-Mud-acid & 101.2 & 0.141 & 22.3 \\
\hline Slurry-MOD-SW & 17.6 & 0.030 & 18.2 \\
\hline Slurry-MOD-SW-Mud-acid & 46.5 & 0.073 & 18.3 \\
\hline
\end{tabular}

Modified slurries have pore diameter values identical to those of standard slurries. However, the Slurry-MOD showed smaller surface area and pore volume. These data suggest that crosslinked Epoxy-EDA polymeric net may reduce the porosity of the slurry and may have influence how the slurry interacts in the presence of acidic aggressive media. Epoxy-EDA polymer can occupy voids in the microstructure of the cement slurry, reducing permeability, ion diffusion and also improving mechanical resistance (Table 2) [48,49].

The mud-acid interactions changed some textural properties of standard slurries. However, for SlurryMOD, these properties have undergone small observable variations $[48,49]$. The surface area, pore volume and pore diameter of the standard slurry increased in size after interaction with mud-acid. For the modified slurries, these changes were less intense, since their pore diameters remained almost unchanged, suggesting that the degradation of these slurries was lower than for the control slurries.

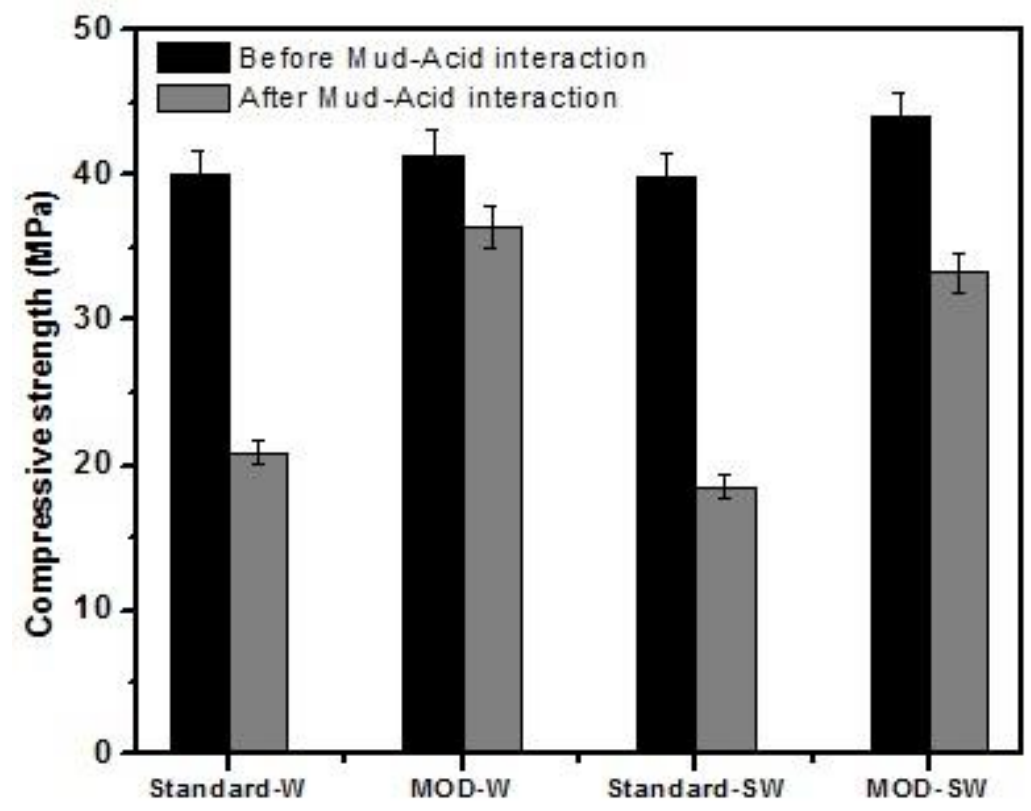

Figure 11: Effect of the interaction of mud-acid on compressive strength of the cement slurries. 
Compressive strength results of the cement slurries are shown in Figure 11. Before the interaction of the cement slurries with mud-acid, the compressive strength has similar values with higher values for the modified pastas. However, after the acid attack, the standard slurries presented a greater decrease than the modified slurries, indicating that the Epoxy-EDA slurries have superior resistance to compression. These results are in good agreement with those obtained by Aggarwal et al (2007) [50]. Those authors showed that the addition of polymers to cement slurries increase compressive strengths and decrease ion penetration, reducing the deterioration of cement slurries. It can conclude that the compressive strength decreases after contact with the mud-acid. However, for standard slurries, these values decrease in greater proportion (approximately 50\%), suggesting a better mechanical resistance for modified slurries.

According to Chen et al (2013) [51], the compressive strength is directly related to the porosity of the material. Cement slurries with higher porosity tend to have lower mechanical strength, as presented in this work. Modified slurries exhibit lower porosity, resulting in a better performance in relation to their mechanical properties, before and after the acid attack.

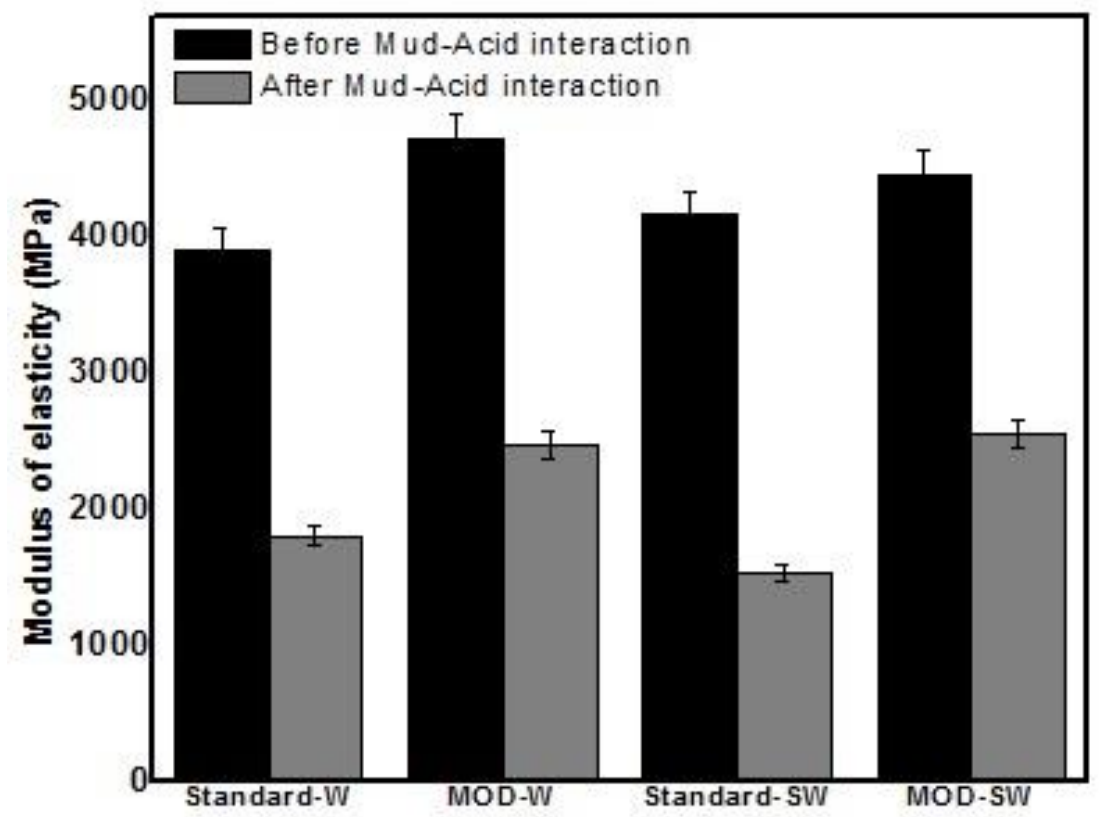

Figure 12: Effect of the interaction of mud-acid on modulus of elasticity of the cement slurries.

The modulus of elasticity of each cement slurries is shown in Figure 12. It is obvious that the modulus of elasticity decreases after mud-acid interaction. However, the addition of Epoxy-EDA polymer improves the modulus of elasticity for cement slurry. The results of the modulus of elasticity are in agreement with literature. Reis (2010) [52] reported that the decrease of the modulus of elasticity of cement slurries after contact with acidic solutions. According that author, the modulus of elasticity also represents a degradation pattern of the material, in which high values indicate less degradation of the cement slurry. In this way, the Figure 12 indicates that the modified slurries presented less chemical degradation against the acid attack than the standard slurries. Therefore, the in situ-formed branched Epoxy-EDA polymeric net seems to have an efficient potential to mitigate the effects of deleterious processes occurring by the use of API fracturing fluids (mud-acid), during routine acidizing procedures in oil and gas industry.

\subsection{Kinetic of mud-acid interaction onto the slurries}

During an acidic attack process, the amount of acid consumed is proportional to the amount of cement in the materials attacked, or more precisely to the content of the hydration products, such as $\mathrm{CH}$. Typically, the rate of acid attack decreases with increasing cement content. Therefore, the neutralization capacity of the cement matrix is evaluated [53]. Figure 13 shows the amounts of acid that interacted with the cement slurries at different temperatures. The amount of acid that reacts increases with the contact time and remains constant after a given contact time (approximately 24 hours), when the interaction equilibrium occurs. As shown, the amount of mud-acid interacting with the cement slurries increases with increasing temperature from 25 to 55 ${ }^{\circ} \mathrm{C}$. Typically, temperature increase enhances acid etching to cement [35]. 
Many attempts have been made to formulate general mathematical expressions, which would be able to adequately describe the kinetics of interaction at solid/solution interfaces. For efficient analysis of the ac$\mathrm{id} /$ cement interactions, it is necessary to use suitable mathematical models to calculate the kinetic parameters of the interactions systems. In this work, a kinetic order-variable exponential function was used, as shown in eq. 7 [54]:

$$
Q_{t}=Q_{e} \cdot\left(1-\exp ^{-(k \cdot t)^{n}}\right.
$$

where $k$ is the kinetic rate $\left(\mathrm{h}^{-1}\right)$ and $n$ is a constant related to the interaction mechanisms.
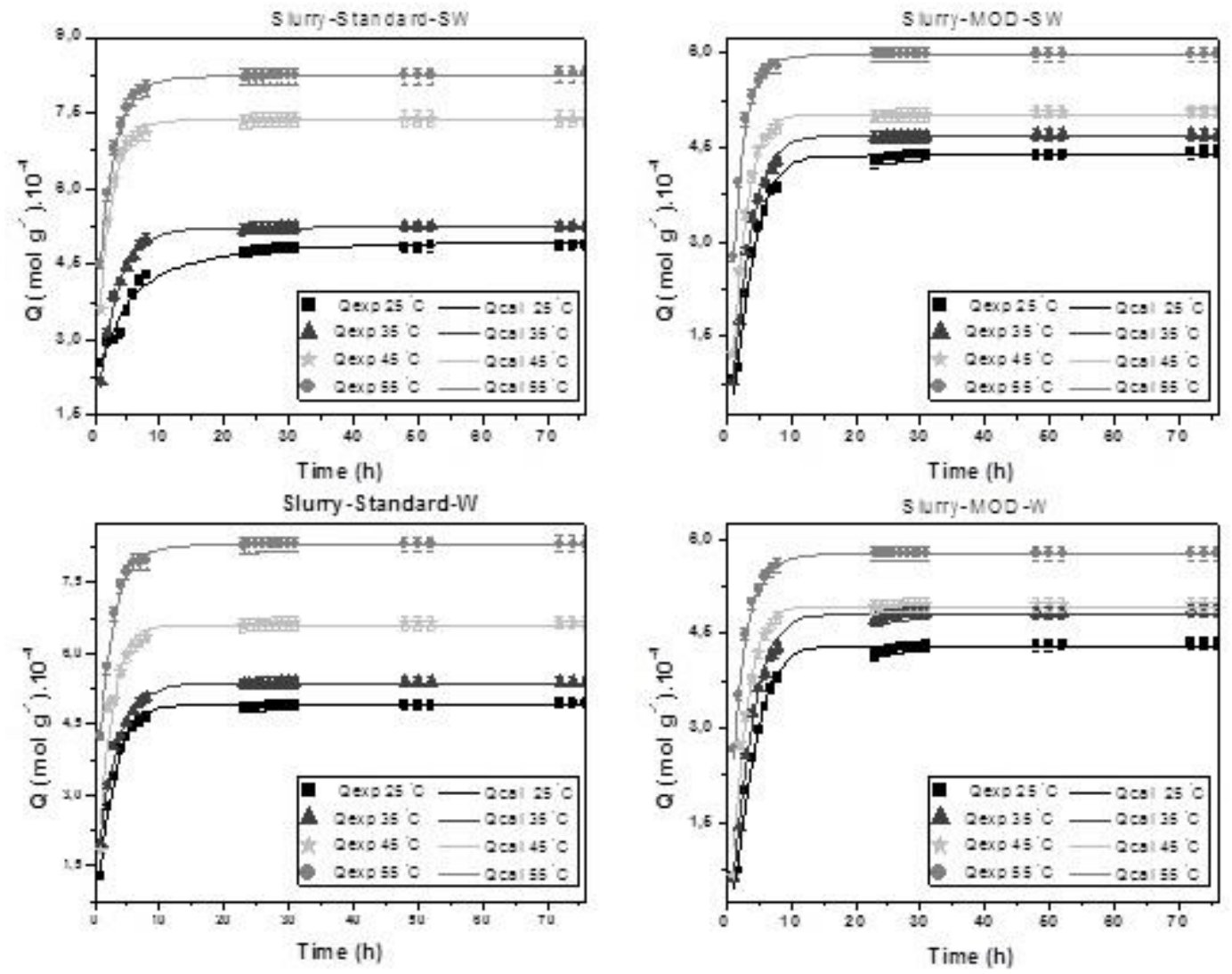

Figure 13: Experimental results (points) and calculated using the kinetic model of variable order (lines) of the interaction of mud-acid with cement slurries. Initial concentration of $\mathrm{H}^{+}=0.10 \mathrm{~mol} \cdot \mathrm{L}^{-1}$.

Figure 13 shows the confrontation of the experimental points with the values obtained from the mathematical model, represented by the lines. The comparison of these data shows that this model was well suited to describe the kinetics of interaction between mud-acid solution and cement slurry. The calculated kinetic parameters are shown in Table 3.

In order to evaluate the fit of the kinetic model, the linear least-squares method $\left(\mathrm{R}^{2}\right)$ was applied. However, $\mathrm{R}^{2}$ is sensitive to extreme experimental data points of the correlations plots, resulting in misleading indication of the quality of a given fit. In this work, the fittings of the kinetic model were done using chisquare $\left(\chi^{2}\right)$ analysis, according to eq. 8 [32]:

$$
X^{2}=\sum \frac{\left(Q_{e}-Q_{m}\right)^{2}}{Q_{m}}
$$

where $\mathrm{Q}_{\mathrm{e}}$ and $\mathrm{Q}_{\mathrm{m}}$ are the acidic amounts at a given time $\mathrm{t}$, which were calculated using experimental data and the kinetic model, respectively. The chi-square statistic test is the sum of the squares of the differences between the experimental data and theoretically predicted data from models. If the calculated data are consistent with the experimental ones, chi-squares will have a small value (generally less than 0.01) [20]. The analysis of the $\mathrm{X}^{2}$ values suggests that the interaction of the mud-acid with slurries can be described by ordervariable exponential model $\left(\mathrm{X}^{2}\right.$ values are lower than $\left.4.31 \times 10^{-3}\right)$. 
Table 3: Kinetic parameters of the interaction of cement slurries with mud-acid.

\begin{tabular}{|c|c|c|c|c|c|c|c|c|}
\hline \multicolumn{9}{|c|}{ SLURRY-STANDARD-W } \\
\hline Temperature $\left({ }^{\circ} \mathrm{C}\right)$ & Q.10 $0^{-4}\left(\mathrm{~mol}^{-\mathrm{g}^{-1}}\right)$ & SD. $10^{-6}$ & $\mathrm{k}\left(\mathrm{h}^{-1}\right)$ & SD & $\mathrm{n}$ & SD & $\mathrm{R}^{2}$ & $\mathrm{X}^{2} \cdot 10^{-3}$ \\
\hline 25 & 4.899 & 1.551 & 0.385 & 0.006 & 1.104 & 0.031 & 0.995 & 0.745 \\
\hline 35 & 5.378 & 1.406 & 0.435 & 0.008 & 0.857 & 0.021 & 0.996 & 0.591 \\
\hline 45 & 6.592 & 5.924 & 0.480 & 0.026 & 1.076 & 0.098 & 0.981 & 1.110 \\
\hline 55 & 8.293 & 1.720 & 0.644 & 0.012 & 0.809 & 0.020 & 0.995 & 0.914 \\
\hline \multicolumn{9}{|c|}{ SLURRY-MOD-W } \\
\hline Temperature $\left({ }^{\circ} \mathrm{C}\right)$ & Q.10 $0^{-4}\left(\mathrm{~mol}_{\mathrm{g}} \mathrm{g}^{-1}\right)$ & SD. $10^{-6}$ & $k\left(h^{-1}\right)$ & SD & $\mathrm{n}$ & SD & $\mathrm{R}^{2}$ & $\mathrm{X}^{2} \cdot 10^{-3}$ \\
\hline 25 & 4.287 & 3.088 & 0.223 & 0.006 & 1.475 & 0.083 & 0.989 & 2.883 \\
\hline 35 & 4.804 & 2.316 & 0.254 & 0.005 & 1.319 & 0.050 & 0.994 & 1.625 \\
\hline 45 & 4.935 & 3.749 & 0.343 & 0.012 & 1.273 & 0.084 & 0.989 & 4.379 \\
\hline 55 & 5.768 & 1.564 & 0.529 & 0.011 & 0.854 & 0.024 & 0.994 & 0.748 \\
\hline \multicolumn{9}{|c|}{ SLURRY-STANDARD-SW } \\
\hline Temperature $\left({ }^{\circ} \mathrm{C}\right)$ & Q.10 $0^{-4}\left(\mathrm{~mol}_{\mathrm{g}} \mathrm{g}^{-1}\right)$ & SD. $10^{-6}$ & $\mathrm{k}\left(\mathrm{h}^{-1}\right)$ & $\mathrm{SD}$ & $\mathrm{n}$ & SD & $\mathrm{R}^{2}$ & $X^{2} .10^{-3}$ \\
\hline 25 & 4.953 & 7.308 & 0.380 & 0.031 & 0.508 & 0.046 & 0.973 & 4.307 \\
\hline 35 & 5.229 & 0.832 & 0.459 & 0.005 & 0.814 & 0.013 & 0.998 & 0.204 \\
\hline 45 & 7.357 & 1.323 & 0.654 & 0.010 & 0.869 & 0.019 & 0.996 & 0.553 \\
\hline 55 & 8.238 & 0.738 & 0.706 & 0.006 & 0.732 & 0.008 & 0.999 & 0.165 \\
\hline \multicolumn{9}{|c|}{ SLURRY-MOD-SW } \\
\hline Temperature $\left({ }^{\circ} \mathrm{C}\right)$ & Q.10 $10^{-4}\left(\mathrm{~mol}_{\mathrm{g}} \mathrm{g}^{-1}\right)$ & SD. $10^{-6}$ & $\mathrm{k}\left(\mathrm{h}^{-1}\right)$ & SD & $\mathrm{n}$ & $\mathrm{SD}$ & $\mathrm{R}^{2}$ & $\mathrm{X}^{2} \cdot 10^{-3}$ \\
\hline 25 & 4.371 & 2.993 & 0.243 & 0.006 & 1.362 & 0.074 & 0.988 & 2.711 \\
\hline 35 & 4.682 & 1.954 & 0.289 & 0.005 & 1.225 & 0.042 & 0.995 & 1.162 \\
\hline 45 & 5.028 & 1.036 & 0.370 & 0.004 & 1.220 & 0.022 & 0.998 & 0.336 \\
\hline 55 & 5.970 & 1.075 & 0.583 & 0.008 & 0.912 & 0.018 & 0.997 & 0.364 \\
\hline
\end{tabular}

The amount of acid that interacted with the standard slurries (Slurry-Standard-SW and SlurryStandard-W) showed higher values than for modified slurries (Slurry-MOD-SW and Slurry-MOD-W). Moreover, the increase in temperature favors the interaction of the slurries with the acid and with and with greater proportion for the slurries without the Epoxy-EDA polymer. Therefore, it can be predicted that standard slurries have higher affinity for the mud-acid solution than the modified slurries.

The analysis of the kinetic parameters indicates that the acid attack is slower in the additived slurries, since it present smaller kinetic constants $(\mathrm{k})$, when compared with the standard slurries. Temperature is an important factor to acid attack onto cement slurries. Normally, chemical reactions occurring at high temperatures give more energy to the system and increases the rate of reaction, causing more collisions between particles, as explained by collision theory. However, the main reason for temperature to increase the reaction rate is that more particles in the collision will have the required activation energy resulting in successful collisions. By analyzing some known effects, such as increase of both reaction rate and solubility of the calcium salts, it can be expected that temperature rise will increase the acid aggressiveness to the cement [55]. In the present study, it was observed that the mud-acid/cement interaction processes are temperature dependent. As temperature increases, the kinetic constants have high values, suggesting fast reaction rates and, thus, more intense acid attacks. The standard slurries have higher values of $k$ than the modified slurries, suggesting that the standard slurries suffered greater aggression from the mud-acid solution.

The values of the kinetic parameter $n$ can provide information concerning the mechanistic features of interaction phenomena at the solid/solution interfaces. Typically, values of $n$ above 1.0 suggest interaction mechanisms occurred on the surface of the slurry. On the other hand, values of this parameter smaller than unity suggest that the mud-acid diffusion process govern these mud-acid/cement interactions [20]. In general, the values of $n$ are close to unity. However, for the standard slurries, the values are lower than for the modified slurries, suggesting diffusion as the predominant mechanism of the attack for the control slurries. At the same time, it suggests that the slurries added with the Epoxy-EDA polymer should make it difficult to diffuse mud-acid into these slurries.

According to the kinetic data, the modified slurries show less interaction with the acid solution, when the reaction occurs at a slower speed. In addition, there is an apparent difficulty of diffusion of the $\mathrm{H}^{+}$ions into the modified-slurries, suggesting also that the inclusion of such epoxy-based polymeric net offers some degree of protection in cement matrix against acid attack. 


\subsection{Evaluation of the mud-acid interaction with cement slurry by multivariate analysis and modeling}

Factorial design is a fast and effective method for understanding and optimizing products and processes. The $2^{\mathrm{k}}$ factorial design is one of the most utilized in the research of effects of different factors on a specific response, where $\mathrm{k}$ is the number of factors analyzed in two levels [55].

The full $2^{4}$ factorial design was performed to evaluate the importance of the parameters: cement slurry type, type of water used for preparation of the slurries, concentration of the mud-acid solution and the temperature on the mud-acid interaction onto the slurries. The responses evaluated were the amount of acid that interacts with the slurry $(\mathrm{Q})$ and the kinetic constant $(\mathrm{k})$, obtained from the kinetic modeling performed with the experimental data. These parameters were selected due to their importance in describing the interactions that occurred in the solid/solution interface [34]. The experimental design was performed using two levels for each selected factor, which were coded as (+) for the higher level and (-) for the lower level, as presented in Table 4. The effect of each factor shows the variation in the response caused by the change from the lower level factor (-1) to the higher level factor $(+)$.

Table 4: Factors and levels used in the $2^{4}$ factorial design study.

\begin{tabular}{c|c|c}
\hline \multirow{2}{*}{ FACTORS } & \multicolumn{2}{|c}{ LEVELS } \\
\cline { 2 - 3 } & $(-)$ & $(+)$ \\
\hline $\mathrm{P}=$ type of slurry & Standard & Epoxy-EDA \\
\hline $\mathrm{C}=$ concentration of $\mathrm{H}^{+}\left(\mathrm{mol}^{-\mathrm{L}^{-1}}\right)$ & 0.01 & 0.1 \\
\hline $\mathrm{T}=$ Temperature $\left({ }^{\circ} \mathrm{C}\right)$ & 25 & 55 \\
\hline $\mathrm{E}=$ Environment for prepared of the slurries & Seawater & Distilled water \\
\hline
\end{tabular}

Table 5: Experimental and predicted results of the $2^{4}$ factorial design.

\begin{tabular}{|c|c|c|c|c|c|c|c|c|}
\hline EXPERIMENT & $\mathbf{P}$ & C & $T$ & $E$ & $\begin{array}{c}\text { Q.10 }^{-4} \\
\text { EXPERIMENTAL } \\
\left(\mathrm{mol}^{-1} \mathrm{~g}^{-1}\right)\end{array}$ & $\begin{array}{c}\text { Q.10 } \\
\text { PREDICTED } \\
\left({\left.\mathrm{mol} . \mathrm{g}^{-1}\right)}^{-4}\right.\end{array}$ & $\begin{array}{c}k\left(h^{-1}\right) \\
\text { EXPERIMENTAL }\end{array}$ & $\begin{array}{c}k\left(h^{-1}\right) \\
\text { PREDICTED }\end{array}$ \\
\hline 1 & -1 & -1 & -1 & -1 & 0.61 & 0.61 & 0.582 & 0.587 \\
\hline 2 & 1 & -1 & -1 & -1 & 0.52 & 0.53 & 0.464 & 0.463 \\
\hline 3 & -1 & 1 & -1 & -1 & 4.95 & 4.95 & 0.380 & 0.385 \\
\hline 4 & 1 & 1 & -1 & -1 & 4.37 & 4.35 & 0.243 & 0.249 \\
\hline 5 & -1 & -1 & 1 & -1 & 0.76 & 0.73 & 0.873 & 0.871 \\
\hline 6 & 1 & -1 & 1 & -1 & 0.67 & 0.69 & 0.700 & 0.703 \\
\hline 7 & -1 & 1 & 1 & -1 & 8.24 & 8.27 & 0.706 & 0.705 \\
\hline 8 & 1 & 1 & 1 & -1 & 5.98 & 5.95 & 0.583 & 0.573 \\
\hline 9 & -1 & -1 & -1 & 1 & 0.61 & 0.61 & 0.591 & 0.589 \\
\hline 10 & 1 & -1 & -1 & 1 & 0.53 & 0.53 & 0.489 & 0.481 \\
\hline 11 & -1 & 1 & -1 & 1 & 4.80 & 4.79 & 0.385 & 0.379 \\
\hline 12 & 1 & 1 & -1 & 1 & 4.20 & 4.19 & 0.223 & 0.227 \\
\hline 13 & -1 & -1 & 1 & 1 & 0.77 & 0.81 & 0.944 & 0.885 \\
\hline 14 & 1 & -1 & 1 & 1 & 0.63 & 0.61 & 0.705 & 0.701 \\
\hline 15 & -1 & 1 & 1 & 1 & 8.20 & 8.19 & 0.644 & 0.639 \\
\hline 16 & 1 & 1 & 1 & 1 & 5.70 & 5.71 & 0.529 & 0.523 \\
\hline
\end{tabular}

Table 5 presents the factorial design $2^{4}$ table. The efficiency of a given factorial design study is affected by the choice of the levels studied. In this study, it was observed that a significant difference between the levels occurred, resulting in a reliable evaluation of the factorial design responses. For Q, values ranged were between $5.20 \times 10^{-5}$ and $8.24 \times 10^{-4}$ mol. $\mathrm{L}^{-1}$, and for $\mathrm{k}$ the range of values was: $0.22-0.944 \mathrm{~h}^{-1}$. The main and interaction effects are presented in Table 6 . The effects errors for each response evaluated were $\mathrm{Q}=2.0 \times 10^{-6}$ mol. $\mathrm{g}^{-1}$ and $\mathrm{k}=3.0 \times 10^{-3} \mathrm{~h}^{-1}$.

The factorial design has shown that the main effects for the kinetic responses are significant and influence the process of interaction between cement slurries and mud-acid solutions. The factors "Concentration of mud-acid solution", "Temperature" and "Environment for prepared of the slurries" increase the main effects of Q. Increasing the concentration and temperature increases the quantitative extension of the mud-acid attack on the slurries. Increasing temperature, the mass transport acts as an important in the mud-acid interaction with the cement slurry. In general, interactions at the solid/solution interfaces increase with temperature, 
because higher temperatures provide faster rates of diffusion of the solution species onto the solid surface [1]. In this way, a greater amount of acid interacts with the cement slurries.

Table 6: Effect values and their standard errors of the $2^{4}$ factorial design.

\begin{tabular}{c|c|c}
\hline EFFECTS & $\mathbf{Q}\left(\mathbf{m o l}_{\mathbf{.}} \mathbf{~}^{-1}\right) . \mathbf{1 0 ^ { - 4 }}$ & $\left.\mathbf{k} \mathbf{h}^{-1}\right)$ \\
\hline Average & $3.22 \pm 0.01$ & $0.560 \pm 0.001$ \\
\hline Principal & & \\
\hline P & $-0.79 \pm 0.02$ & $-0.143 \pm 0.003$ \\
\hline C & $5.17 \pm 0.02$ & $-0.204 \pm 0.003$ \\
\hline T & $1.29 \pm 0.02$ & $0.288 \pm 0.003$ \\
\hline E & $-0.08 \pm 0.02$ & $-0.013 \pm 0.003$ \\
\hline & & \\
\hline Interactions & & \\
\hline P-C & $-0.69 \pm 0.02$ & $0.006 \pm 0.003$ \\
\hline P-T & $-0.46 \pm 0.02$ & $-0.010 \pm 0.003$ \\
\hline P-E & $-0.04 \pm 0.02$ & $-0.004 \pm 0.003$ \\
\hline C-T & $1.15 \pm 0.02$ & $0.020 \pm 0.003$ \\
\hline C-E & $-0.08 \pm 0.02$ & $-0.023 \pm 0.003$ \\
\hline T-E & $-0.005 \pm 0.02$ & $-0.013 \pm 0.003$ \\
\hline P-C-T & $-0.44 \pm 0.02$ & $0.021 \pm 0.003$ \\
\hline P-C-E & $-0.03 \pm 0.02$ & $0.001 \pm 0.003$ \\
\hline P-T-E & $-0.04 \pm 0.02$ & $-0.004 \pm 0.003$ \\
\hline C-T-E & $0.01 \pm 0.02$ & $-0.011 \pm 0.003$ \\
\hline P-C-T-E & $-0.02 \pm 0.02$ & $0.008 \pm 0.003$ \\
\hline
\end{tabular}

Water is an important component of cement slurry, contributing actively to the hydration of the cement and its workability when fresh. All compounds present in the cement are anhydrous, but in contact with water it is hydrolyzed forming hydrated compounds. As the water participates in the formation of the cement slurry, the origin of this liquid must be evaluated during the process so that no problems occur in the properties in the cement slurry. However, in practice, water quality control is often neglected [15]. Thus, evaluating the quality of cement slurries in separate aqueous media becomes necessary and can provide economically and ecologically feasible responses for practical applications.

The aqueous medium, in which the slurries were prepared, seawater or distilled water, influences the process of interaction of cement slurries with mud-acid. The slurry prepared in seawater have a higher interaction with the acid than the slurry prepared in distilled water. The slurries prepared with seawater show greater affinity with the acid, corroborating with more corrosion in these slurries. By analyzing the slurry type factor, it is observed that its main effect decreased, indicating that the interaction of the acid species is lower for the Slurry-MOD than the standard slurries.

The temperature factor increased the main effect of $\mathrm{k}$. The interaction of the acid mud with the cement slurries occurs more rapidly at higher temperatures. At lower temperatures, the interaction of mud-acid is driven by external mass transport, and the interaction rate constants $(\mathrm{k})$ are lower than the interaction rate constants at high temperatures. When temperature increases, the thickness of the boundary layer around the slurry surface decreases and the resistance to mass transport of the acid species in solution increases [32].

The factors cement slurry cement, mud-acid concentration and Environment for prepared of the slurries decreased the main effect of $\mathrm{k}$. At lower concentrations, the acid mud is consumed rapidly and a reaction enters into equilibrium. However, the acidic corrosion intensity increases with increasing mud-acid concentration. The resistance of the surface layer also depends on concentration of the acid solution. Increasing acid concentration may result in a variation in the composition of the corroded surface layer of the slurry, due to increased decalcification or dissolution of corrosion products [56].

Despite the higher interaction of the acid with the slurries prepared in seawater, the speed of this reaction was slower in relation to the slurry prepared with distilled water. The reaction rate for the Epoxy-EDA slurries was lower than for the standard slurry, suggesting that the diffusion of the acid occurred more slowly in the modified slurries compared to the standard slurries.

The effects interactions most significant of Q were Cement Slurry Type-Mud-acid Concentration, Temperature- Mud-acid Concentration, and Temperature- Environment for prepared of the slurries. Only two 
interactions are not significant with respect to effects errors, Cement Slurry Type-Temperature and Cement Slurry Type -Mud-acid Concentration-Temperature. In the interactions where the Cement Slurry Type factor is present, the interaction decreases, suggesting that by changing the factors, the Slurry-MOD has less interaction with the acid than the standard slurry.

The interactions of the most significant $\mathrm{k}$ effects were: Mud-acid concentration - Environment for prepared of the slurries, Cement Slurry Type -Temperature, Mud-acid Concentration-Temperature. Some interactions were not considered statistically significant according to their effects errors.

Quantitative polynomial models for $\mathrm{Q}$ and $\mathrm{k}$ can be written using the statically significant effects, from data of Table 5:

$$
\begin{aligned}
& \mathrm{Q}\left(\mathrm{x} 10^{-4}\right)=3.22-0.24 \mathrm{x}_{1}+2.58 \mathrm{x}_{2}+0.65 \mathrm{x}_{3}-0.04 \mathrm{x}_{4}-0.35 \mathrm{x}_{1} \mathrm{x}_{2}-0.23 \mathrm{x}_{1} \mathrm{x}_{3}-0.02 \mathrm{x}_{1} \mathrm{x}_{4}+0.58 \mathrm{x}_{2} \mathrm{x}_{3}- \\
& 0.04 \mathrm{x}_{2} \mathrm{x}_{4}-0.22 \mathrm{x}_{1} \mathrm{x}_{2} \mathrm{x}_{3}-0.02 \mathrm{x}_{1} \mathrm{x}_{3} \mathrm{x}_{5} \\
& \mathrm{k}=0.560-0.07 \mathrm{x}_{1}-0.1 \mathrm{x}_{2}+0.14 \mathrm{x}_{3}-0.007 \mathrm{x}_{4}+0.003 \mathrm{x}_{1} \mathrm{x}_{2}-0.005 \mathrm{x}_{1} \mathrm{x}_{3}+0.01 \mathrm{x}_{2} \mathrm{x}_{3}-0.011 \mathrm{x}_{2} \mathrm{x}_{4}-0.006 \mathrm{x}_{3} \mathrm{x}_{4} \\
& +0.01 \mathrm{x}_{1} \mathrm{x}_{2} \mathrm{x}_{3}-0.005 \mathrm{x}_{2} \mathrm{x}_{3} \mathrm{x}_{4}+0.004 \mathrm{x}_{1} \mathrm{x}_{2} \mathrm{x}_{3} \mathrm{x}_{4}
\end{aligned}
$$

where $\mathrm{x}_{1}, \mathrm{x}_{2}, \mathrm{x}_{3}$ and $\mathrm{x}_{4}$ are codified $( \pm 1)$ values of slurry, concentration of mud-acid, temperature and environment for prepared of the slurries, respectively.

The experimental and predicted values of $\mathrm{Q}$ and $\mathrm{k}$ are also shown in Table 5. Good correlations are observed relating the observed and predicted values of $\mathrm{Q}$ and $\mathrm{k}$.

\section{CONCLUSIONS}

In this study, an epoxy-ethylenediamine cement slurries was synthesized in two aqueous environments: distilled water and seawater. The characterization has pointed out significant compositional differences of the slurries. It was found lower amounts of portlandite in the polymer-modified slurries. The crystalline patterns of such slurries were preserved, before and after mud-acid interactions. On the other hand, the standard slurries have presented significant modifications after contact with mud-acid solution. It is noted that the standard slurries decreased drastically their crystalline features after mud-acid interaction. The analysis of the textural properties of the cement slurries indicated that the control slurries have greater porosity before and after the acid attack than the modified slurries, contributing to a lower chemical and mechanical resistance. Mechanical tests have shown that control slurries have less mechanical resistance than modified slurries.

The kinetic data of the interaction of the additive slurries with acidic species of mud-acid in solution were well fitted to an order-variable exponential kinetic model. The analysis of the kinetic modeling and characterization suggests that surface reactions with preservation of the chemical structures constitute the main mechanistic interactions at the interface of polymer-modified cement slurries, even after long-term contact with mud-acid.

Additional testing procedures must be performed to validate the use of the Epoxy-EDA-modified cement slurries in oil well cementing operations. However, the characterization and the factorial design results have suggested that this new cement slurry presents good potential to be used in innovative environmentalfriendly oil well procedures.

\section{BIBLIOGRAPHY}

[1] Hewlett, P. C., Lea's Chemistry of Cement and Concrete; 4 ed., Burlington, Elsevier, 2003.

[2] JR, F.M., TREVISAN, O.V., "Thermal analysis in matrix acidization", Journal of Petroleum Science \& Engineering, v. 51, n. 1-2, pp. 85-96, April 2006.

[3] KHAIRUL, N., BIN, I., AB, N., et al., "Slagment Cement Improve the Cement Resistance Toward Acids Attack During Acidizing Treatment", Journal of Applied Sciences, Engineering and Technology, v. 5, n. 21, pp. 4961-4966, May 2013.

[4] OK, D., D, A., OF, J., et al., "Compatibility: A Key to An Efficient Matrix Acidizing Fluid Design", Journal of Petroleum \& Environmental Biotechnology, v. 7, n. 2, pp. 1-5, April 2016.

[5] RAJEEV, P., SURENDRANATHAN, A.O., MURTHY, C. S.N., "Corrosion mitigation of the oil well steels using organic inhibitors-A review", Journal of Materials and Environmental Science, v. 3, n. 5, pp. 856-869, June 2012. 
[6] CESTARI, A.R., VIEIRA, E.F.S., PINTO, A.A., et al., "Synthesis and characterization of epoxymodified cement slurries - Kinetic data at hardened slurries / $\mathrm{HCl}$ interfaces", Journal of Colloid and Interface Science, v. 327, n. 2, pp. 267-274, November 2008.

[7] CRÉPY, L., PETIT, J., WIRQUIN, E., et al., "Synthesis and evaluation of starch-based polymers as potential dispersants in cement slurries and self-leveling compounds", Cement and Concrete Composites, v. 45, pp. 29-38, January 2014.

[8] PIQUE, T.M., BAUEREGGER, S., PLANK, J., "Influence of temperature and moisture on the shelf-life of cement admixed with redispersible polymer powder", Construction and Building Materials, v. 115, pp. 336-344, July 2016.

[9] DJOUANI, F., CONNAN, C., CHEHIMI, M., et al., "Interfacial chemistry of epoxy adhesives on hydrated cement slurry", Surface and Interface Analysis, v.40, n. 3-4, pp. 146-150, March-April 2008.

[10] SAOUT, G. LE, LÉCOLIER, E., RIVEREAU, A., et al., "Chemical structure of cement aged at normal and elevated temperatures and pressures: Part I. Class G oilwell cement", Cement and Concrete Research, v. 36, n. 1, pp. 71-78, January 2006.

[11] TORRES, R. B.; SANTOS, J. C. DOS; PANZERA, T. H.; et al. "Hybrid glass fibre reinforced composites containing silica and cement microparticles based on a design of experiment". Polymer Testing, v. 57, pp. 87-93, February 2017.

[12] Czarneck, L. Adhesion-A Challenge for Concrete Repair. In concrete repair, rehabilitation and retrofitting II, Alexander, M. G., 1 Ed., London, Taylor \& Francis, 2008.

[13] ANAGNOSTOPOULOS, C.A., SAPIDIS, G., PASLURRYRGIADIS, E., "Fundamental properties of epoxy resin-modified cement grouts", Construction and Building Materials, v. 125, pp. 184-195, October 2016.

[14] WEERDT, K.DE., JUSTNES, H., "The effect of seawater on the phase assemblage of hydrated cement paste", Cement and Concrete Composites, v. 55, pp. 215-222, January2015.

[15] WEERDT, K.DE., JUSTNES, H., GEIKER, M.R., "Changes in the phase assemblage of concrete exposed to seawater", Cement and Concrete Composites, v. 47, pp. 53-63, March 2014.

[16] API (American Petroleum Institute). Recommended practice for testing well cements.22 Ed., 1997.

[17] VIEIRA, E.F.S., LIMA, P.F., SANTOS, I.M.G., et al., "The Influence of In Situ Polymerized Epoxidized A / F Bisphenol-Chitosan on Features of Oilwell Cement Slurry - Molecular-Level Analysis and Long-Term Interaction of API Fracturing Fluid", Journal of Applied Polymer Science, v. 41044, n. 22, pp. 19, May 2014.

[18] CESTARI, A.R., VIEIRA, E.F.S., TAVARES, A.M.G., et al,. "Cement-epoxy/water interfaces - Energetic, thermodynamic, and kinetic parameters by means of heat-conduction microcalorimetry", Journal of Colloid and Interface Science, v. 343, n. 1, pp. 162-167, March 2010.

[19] EAGLESON, M. Concise Encyclopedia Chemistry. New York, Berlin, Walter de Gruyter, 1994.

[20] REDDY, B.M., RAO, H.S., GEORGE, M. P., et al., "Effect of Hydrochloric Acid (HCl) on Blended Cement (Fly Ash based) and Silica Fume Blended Cement and their Concretes", International Journal of Science and Technology, v. 1, n. 9, pp. 476- 480, September 2012.

[21] MARTINEZ-RAMIREZ, S., FRIAS, M., DOMINGO, C., "Micro-Raman spectroscopy in White Portland cement hydration: long-term study at room temperature", Journal of Raman Spectroscopy, v. 37, n. 5, pp. 555-561, May 2006.

[22] HIDALGO, A., DOMINGO, C., GARCIA, C., et al., "Microstructural changes induced in Portland cement-based materials due to natural and supercritical carbonation", Journal of Materials Science, v. 43, n.9, pp. 3101-3111, February 2008.

[23] SARAYA, M.E.S.I., "Study physico-chemical properties of blended cements containing fixed amount of silica fume, blast furnace slag, basalt and limestone, a comparative study", Construction and Building Materials, v. 72, pp.104-112, December 2014.

[24] JO, B.W., CHAKRABORTY, S., LEE, Y.S., "Hydration study of the polymer modified jute fibre reinforced cement slurry using analytical techniques", Construction and Building Materials, v. 101, pp. 166-173, December 2015.

[25] GENG, J., EASTERBROOK, D., LI, L.-Y., et al., "The stability of bound chlorides in cement paste with sulfate attack", Cement and Concrete Research, v. 68, pp. 211-222, February 2015. 
[26] CHEN, L., WANG, X., JIA, Z., et al., "Use of precipitated silica with silanol groups as an inorganic chain extender in polyurethane", Materials \& Design, v. 87, pp. 324-330, December 2015.

[27] BLACK, L., BREEN, C., YARWOOD, J., et al., "Hydration of tricalcium aluminate $\left(\mathrm{C}_{3} \mathrm{~A}\right)$ in the presence and absence of gypsum-studied by Raman spectroscopy and X-ray diffraction", Journal of Materials Chemistry, v. 16, n. 13, pp. 1263-1272, January 2006.

[28] JENNI, A., HOLZER, L., ZURBRIGGEN, R., HERWEGH, M. "Influence of polymers on microstructure and adhesive strength of cementitious tile adhesive mortars", Cement and Concrete Research, v. 35, n. 1, pp. 35-50, January 2005.

[29] KAMSEU, E., CHIARA, M., MELO, U.C., et al., Design of inorganic polymer cements : Effects of matrix strengthening on microstructure. Construction and Building Materials, v. 38, pp. 1135-1145, January 2013.

[30] DJOUANI, F., CONNAN, C., DELAMAR, M., et al., "Cement slurry - epoxy adhesive interactions", Construction and Building Materials, v. 25, n.2, pp. 411-423, February 2011.

[31] BORDY, A.; YOUNSI, A.; AGGOUN, S.; FIORIO, B. Cement substitution by a recycled cement paste fine: Role of the residual anhydrous clinker. Construction and Building Materials, v. 132, n. 1, pp. 1-8, February 2017.

[32] CESTARI, A.R., VIEIRA, E.F.S., ALVES, F.J., et al., "A novel and efficient epoxy / chitosan cement slurry for use in severe acidic environments of oil wells - Structural characterization and kinetic modeling", Journal of Hazardous Materials, v. 213-214, pp. 109-116, April 2012.

[33] KNAPEN, E., GEMERT, D.V., "Cement hydration and microstructure formation in the presence of water-soluble polymers", Cement and Concrete Research, v. 39, n. 1, pp. 6-13, January 2009.

[34] GAO, X.X., CYR, M., MULTON, S., et al., "A comparison of methods for chemical assessment of reactive silica in concrete aggregates by selective dissolution", Cement and Concrete Composites, v. 37, n. 1, pp. 82-94, March 2013.

[35] CHEN, J. J.; THOMAS, J. J.; JENNINGS, H. M. "Decalcification shrinkage of cement paste". Cement and Concrete Research, v. 36, n.5, pp. 801-809, May 2006.

[36] ELMOATY, A.E.M.A., "Mechanical properties and corrosion resistance of concrete modified with granite dust", Construction and Building Materials, v. 47, pp. 743-752, October 2013.

[37] ZIVICA, V., BAJZA, A., "Acidic attack of cement-based materials - a review Part 2. Factors of rate of acidic attack and protective measures", Construction and Building Materials, v. 16, n.4, pp.215-222, June 2002.

[38] PALOMO, A., GRUTZECK, M.W., BLANCO, M.T., "Alkali-activated fly ashes: A cement for the future", Cement and Concrete Research, v. 29, n. 8, pp. 1323-1329, August 1999.

[39] SHI, Z.; GEIKER, M. R.; LOTHENBACH, B.; et al. Friedel's salt profiles from thermogravimetric analysis and thermodynamic modelling of Portland cement-based mortars exposed to sodium chloride solution. Cement and Concrete Composites, v. 78, pp. 73-83, April 2017.

[40] LUDWIG, H.M., ZHANG, W., "Research review of cement clinker chemistry", Cement and Concrete Research, v. 78, pp. 24-37, December 2015.

[41] ABO-EL-ENEIN, S.A., EL-KADY, G., EL-SOKKARY, T.M., GHARIEB, M. "Physico-mechanical properties of composite cement slurries containing silica fume and fly ash", HBRC Journal, v. 11, n. 1, pp. 715, April 2015.

[42] YLMÉN, R., WADSÖ, L., PANAS, I., "Insights into early hydration of Portland limestone cement from infrared spectroscopy and isothermal calorimetry", Cement and Concrete Research, v. 40, n. 10, pp. 15411546, October 2010

[43] SAOU, G.L.; LÉCOLIER, E., RIVEREAU, A., et al., "Chemical structure of cement aged at normal and elevated temperatures and pressures, Part II : Low permeability class G oil well cement", Cement and Concrete Research, v. 36, n.3,pp. 428-433, March 2006.

[44] JAKOBSEN, H.J., POULSEN, S.L., KOCABA, V., et al., "Improved quantification of alite and belite in anhydrous Portland cements by Si MAS NMR: Effects of paramagnetic ions". Solid State Nuclear Magnetic Resonance, v. 36, n. 1, pp. 32-33,September 2009.

[45] SEN, S., YOUNGMAN, R.E., "High-Resolution Multinuclear NMR Structural Study of Binary Aluminosilicate and Other Related Glasses", Journal of Physical Chemistry B, v.108, n. 23, pp. 7557-7564, May 2004. 
[46] PAUL, G., BOCCALERI, E., BUZZI, L., et al., "Friedel's salt formation in sulfoaluminate cements: A combined XRD and Al MAS NMR study", Cement and Concrete Research, v. 67, pp. 93-102, January 2015.

[47] GASTALDI, D., PAUL, G., MARCHESE, L., et al., "Hydration products in sulfoaluminate cements: Evaluation of amorphous phases by XRD / solid-state NMR", Cement and Concrete Research, v. 90, pp.162173, December 2016.

[48] WANG, W., LIU, P., ZHANG, M., et al., "The Pore Structure of Phosphoaluminate Cement", Open Journal of Composite Materials,v.2, n.3, pp. 104-112, July 2012.

[49] SILVA, D.A., JOHN, V.M., RIBEIRO, J.L.D., et al., "Pore size distribution of hydrated cement slurries modified with polymers”, Cement and Concrete Research, v. 31, n. 8, pp. 1177-1184, August 2001.

[50] AGGARWAL, L.K., THAPLIYAL, P.C., KARADE, S.R., "Properties of polymer-modified mortars using epoxy and acrylic emulsions", Construction and Building Materials, v. 21, n. 2, pp. 379-383, February 2007.

[51] CHEN, X.; WU, S.; ZHOU, J. "Influence of porosity on compressive and tensile strength of cement mortar", Construction and Building Materials, v. 40, pp. 869-874, March 2013.

[52] REIS, J.M.L., "Fracture assessment of polymer concrete in chemical degradation solutions", Construction and Building Materials, v. 24, n. 9, pp. 1708-1712, September 2010.

[53] ZIVICA, V., PALOU, M.T., KRIZMA, M., et al., "Acidic attack of cement based materials under the common action of high, ambient temperature and pressure", Construction and Building Materials, v. 36, pp. 623-629, November 2012.

[54] LOPES, E.C.N., ANJOS, F.S.C., VIEIRA, E.F.S., et al., "An alternative Avrami equation to evaluate kinetic parameters of the interaction of $\mathrm{Hg}$ (II) with thin chitosan membranes", Journal of Colloid and Interface Science, v. 263, n.2, pp. 542-547, July 2003.

[55] SANTILLI, A., PUENTE, I., TANCO, M., "Fresh concrete lateral pressure decay: Kinetics and factorial design to determine significant parameters", Engineering Structures, v. 52, pp. 114-122, July 2013.

[56] ALLAHVERDI, A.L.I., ŠKVÁRA, F., “Acidic corrosion of hydrated cement based materials part 2. Kinetics of the phenomenon and mathematical models", Ceramics, v. 44, n. 4, pp. 152-160, May 2000.

\section{ORCID}

Danilo Oliveira Santos Ivory Marcos Gomes dos Santos Joenesson Filip Santos Ribeiro Eunice Fragoso Silva Vieira Gwenn Le Saoût Antonio Reinaldo Cestari
http://orcid.org/0000-0003-3306-429X https://orcid.org/0000-0001-5699-0080 https://orcid.org/0000-0001-9188-5585 https://orcid.org/0000-0003-2599-3208 https://orcid.org/0000-0002-2761-0584 https://orcid.org/0000-0002-7594-3279 